\title{
Extreme energy, 'fracking' and human rights: a new field for human rights impact assessments?
}

\author{
Damien Short*, Jessica Elliot, Kadin Norder, Edward Lloyd-Davies and Joanna Morley
}

Human Rights Consortium, School of Advanced Study, University of London, UK

\begin{abstract}
This article explores the potential human rights impacts of the 'extreme energy' process, specifically focussing on the production of shale gas, coal-bed methane (CBM) and 'tight oil', known colloquially as 'fracking'. The article locates the discussion within a broader context of resource depletion, the 'limits to growth' and the process of extreme energy itself. Utilising recent secondary data from the United States and Australia, combined with the preliminary findings of our ethnographic fieldwork in the United Kingdom, the article outlines a prima facie case for investigating 'fracking' development through a human rights lens. Indeed, based on considerable emerging evidence we argue that 'fracking' development poses a significant risk to a range of key human rights and should thus form the subject of a multitude of comprehensive, interdisciplinary human rights impact assessments (HRIAs) as a matter of urgency. Finally, given the close relationships between government and extractive industries, we argue that these impact assessments must do more than bolster corporate social responsibility (CSR) statements and should be truly independent of either government or industry influence.
\end{abstract}

Keywords: extreme energy; fracking; human rights; impact assessments; environment; hydraulic fracturing; corporate social responsibility

\section{Introduction}

\section{Limits to growth, extreme energy and the 'minimally good life'}

While the theory and practice of 'human rights' has produced many differing conceptions, justifications, formulations and relativistic exceptions, ${ }^{1}$ for the purposes of this article we will principally utilise the relatively uncontentious, empirically grounded, 'minimalist' ${ }^{2}$ conception articulated by legal scholar James Nickel. For Nickel, contemporary human rights standards are justified moral and legal claims 'universally held' by all persons visà-vis their governments, coupled with their corresponding moral and legal duties that governments, at all levels, owe their citizens in order for them to lead a 'minimally good life'. 3 National and international institutions bear the primary responsibility of securing human rights and the test for successfully fulfilling this responsibility is the creation of opportunities for all individuals to lead such a life. The realisation of human rights requires establishing the conditions, positive and negative, for all human beings to lead minimally good lives and thus should not be confused with attempts to promote the highest possible standards of living, or the best or most just form of economic system, or a morally perfect

*Corresponding author. Email: Damien.short@sas.ac.uk 
society. The impression that many have of human rights as being unduly utopian testifies less to the inherent demands of human rights and more to the extent to which the fairly modest aspiration of a "minimally good life ${ }^{4}$ for all is so far from being realised in the world today. Here, we are not just talking about the seemingly infinite number of discrete human rights violations around the world, about which much has been written, but also the systemic denial of the 'minimally good life' for millions of people that seems to be the inevitable by-product of the capitalist mode of production ${ }^{5}$ and about which much less has been written. Perhaps the most well-known debate in the human rights literature is the exchange between Rhoda Howard-Hassman and Admandiata Pollis. The debate highlighted contrasting interpretations of the pros and cons of the spread of global capitalism for human rights, but it is the former's ${ }^{6}$ faith in capitalism's 'long term' prospects for the enhancement of human rights that is symptomatic of a distinct academic and popular denial of the two most important and unsavoury facts facing humanity today - the 'limits to growth' and anthropogenic climate change.

The 1972 Club of Rome report The Limits to Growth ${ }^{7}$ utilised a system dynamics computer model to simulate the interactions of five global economic subsystems, namely: population, food production, industrial production, pollution and consumption of non-renewable natural resources, the results of which posed serious challenges for global sustainability. A recent study collated historical data for 1970-2000 and compared them with scenarios presented in The Limits to Growth. The analysis shows that 30 years of historical data compares favourably with key features of the 'standard run' scenario, which results in collapse of the global system midway through the twenty-first century. The key driver behind the Limits to Growth prediction - and arguably the one most poised to quickly cause global economic collapse - is the depletion of non-renewable energy sources, especially of oil and natural gas. ${ }^{9}$ Despite the best efforts of the fossil fuel industry to propagate a paradigm of energy abundance, especially in the United States (US), ${ }^{10}$ global production of conventional oil has already peaked and - barring incredibly unlikely huge new discoveries of easily extracted oil - must soon decline as predicted in Limits to Growth. ${ }^{11}$ New discoveries of oil and natural gas liquids ${ }^{12}$ have dropped dramatically since their peak in the 1960s, and the world now consumes four to five barrels of oil for every one discovered. ${ }^{13}$ Because oil production from conventional fields drops globally by $5 \%$ each year, it is thus assured that such fields will eventually 'run out'. ${ }^{14}$

This downward global trend in oil discovery and supply has not gone unnoticed by the major international actors, namely states and multi- and trans-national corporations, who have taken various actions since the end of the Cold War to secure access to remaining conventional oil supplies. An examination of major international conflicts in the Persian Gulf region alone since 1990 demonstrates the determination of countries such as the US to maintain control of conventional energy resources. ${ }^{15}$ Indeed, conventional energy supplies have become so precious to many states that "energy security" ${ }^{16}$ is now an overriding objective within which foreign and domestic policies situate the procurement of oil (and other energy sources) as a matter of national security. Such a discourse often elevates concern for the global fossil fuel market over other considerations such as the environment and human rights. ${ }^{17}$

This change in rhetoric to boost the perceived necessity of fossil fuels is furthered by the influence of major energy corporations upon state governments. As numerous internationally reaching corporations, such as Exxon Mobil and ConocoPhillips, have developed larger economies than many sizeable states, ${ }^{18}$ their power has correspondingly grown. Since such companies' business models centre on fossil fuels, examples of corporate-state collaboration to further non-renewable energy use may be found in varying arenas, from 
the more than 50 million dollars Koch Industries spent on lobbying the US government between 1998 and $2010^{19}$ and the formation of the American Legislative Exchange Council (which brings private corporations together with elected US state officials to draft new legislation), ${ }^{20}$ to direct connections between advisors to the United Kingdom (UK) Cabinet Office and energy sector companies such as Centrica and Riverstone. ${ }^{21}$ Because of the overly close, arguably corrupt and undemocratic relationships, ${ }^{22}$ between politicians and corporate interests, it could be argued that the exclusion of 'the underground injection of natural gas for purposes of storage' and ' $\ldots$ of fluids or propping agents ... pursuant to hydraulic fracturing operations related to oil, gas, or geothermal production activities' from the US Safe Drinking Water $\mathrm{Act}^{23}$; the British government's determination to make unconventional energy extraction through hydraulic fracturing an 'urgent national priority $^{24}$; the failure of the European Union to create legally binding environmental legislation for hydraulic fracturing ${ }^{25}$; and George W. Bush's administration's policy of attempting to 'refute the science of global warming and install in its place economic and environmental policies that not only ignore but deny the views of the scientific community on climate change ${ }^{, 26}$ are - at the very least in part - results of the wishes of the energy sector. As the 200 largest listed fossil fuel companies spent $\$ 674$ billion on developing new energy reserves (five times as much as they spent returning money to shareholders) in $2012,{ }^{27}$ the energy industry remains invested in pushing the 'limits' as far as they can go. ${ }^{28}$

Though corporations may lobby otherwise, ${ }^{29}$ resource limitations to growth are not the only significant, impending, ecological threats to human rights on a global scale. Carbon dioxide atmospheric concentrations 'have increased by $40 \%$ since pre-industrial times', with concentrations of carbon dioxide, methane and nitrous oxide at the highest in at least 800,000 years, ${ }^{30}$ and the rate of carbon dioxide release is unprecedented, at least in the last 300 million years. The result of this level of pollution - inherently tied to an insistence on using and depleting non-renewable energy sources ${ }^{31}-$ is the phenomenon of climate change, in this context represented by the anthropogenic increase in the earth's surface temperature. Since 1880, the average global temperature has increased by roughly 0.85 degrees Celsius, with most of the increase -0.72 degrees Celsius - occurring in the past 50 years. ${ }^{32}$ The effects of this global warming are diverse and range from shrinking glaciers and ice sheets, to the highest rate of sea level rise in the past 2000 years and increasingly frequent extreme weather events; all of which clearly result from 'human influence on the climate system'. ${ }^{33}$

Knowing that these two results of humanity's 'addiction' to fossil fuels are imminently approaching, it may be hoped that global use of oil, natural gas and coal are immediately curbed. At present, however, fossil fuels still remain the world's main source of energy, accounting for $81 \%$ of global primary energy use in $2010 .^{34}$ This is undoubtedly due, at least in part, to the current, Western propagated, largely fossil fuel dependent, neoliberal economic model, wherein corporations, being legally bound to pursue profit above all other considerations, continuously, and most often successfully, lobby for favourable legislation, deregulation and tax incentives. As Bakan noted in his seminal text, The Corporation: The Pathological Pursuit of Profit and Power, ${ }^{35}$ under corporate law, the primary legal duty of the corporation is 'simply to make money for shareholders' and failing to pursue this end 'can leave directors and officers open to being sued. ${ }^{36}$ Thus, the multitude of multi-billion dollar companies that depend upon the continued global use of fossil fuels have not only a vested interest in advocating for further non-renewable energy extraction, but arguably, in the current energy market, a legal duty to do so - and at the very least an obligation to continue pursuing oil, coal and natural gas extraction as long as it is profitable (and legal) to do so. Thus, while the use of renewable energy sources is growing, ${ }^{37}$ they are 
forced to compete with an established and highly subsidised ${ }^{38}$ non-renewable market, rather than be allowed to replace it. ${ }^{39}$

Furthermore, as conventional reserves are depleted ${ }^{40}$ and demand for energy rises, there is increasing pressure to exploit unconventional energy sources. ${ }^{41}$ Michael Klare ${ }^{42}$ first coined the term 'extreme energy' to describe a range of relatively new, higher-risk, non-renewable resource extraction processes that have become more attractive to the conventional energy industry as the more easily accessible supplies dwindle. Edward LloydDavies points out, however, that this definition of extreme energy as a category is highly problematic as it is dependent upon specific examples; it lacks 'explanatory or predictive power', ${ }^{43}$ and leaves open the question of who decides which extractive techniques qualify. A conceptual understanding would suggest that extreme energy is a "process whereby extraction methods grow more intense over time, as easier to extract resources are depleted'. The foundation of this conception is the simple fact that those energy sources which require the least amount of effort to extract will be used first, and only once those are dwindling will more effort be exerted to gain similar resources. Extreme energy, in this sense, is evident in the history of energy extraction - in the change from gathering 'sea coal' from British beaches and exploiting 'natural oil seeps', to opencast mining and deep-water oil drilling. Viewed in this light, the concept of extreme energy becomes a lens through which current energy extraction efforts can be explained and the future of the energy industry predicted. Using this extreme energy lens necessitates an understanding of 'the amount of energy which is needed to obtain energy', as in this process it is that value which is continually rising. This value may be calculated as either 'net energy' or 'energy return on investment' (EROI), whereby net energy is the available energy for use after subtracting the energy required for extraction, and EROI is the percentage of energy produced divided by the amount required for extraction. When charted together, the net energy available to society is seen to decrease along with EROI in a curved mathematical relationship which forms the 'energy cliff' - i.e. the point at which EROI becomes increasingly low and net energy drops to zero. ${ }^{44}$

In the extreme energy process the economic system can be conceptualised as consisting of two distinct segments, the part which is extracting, refining and producing energy (the energy industry) and everything else, which just consumes energy. What needs to be clearly understood is that the energy industry is in the rare position where the commodity which it produces is also the main resource it consumes. Therefore, as energy extraction becomes more extreme, while the rest of the economy will be squeezed by decreasing energy availability and rising prices, ${ }^{45}$ the energy industry's rising costs will be offset by the rising revenues it receives. The net result will be a reallocation (through the market or otherwise) of resources from the rest of society to the energy industry, to allow the energy industry to target ever more difficult to extract resources. This process is ongoing as easier-to-extract resources are depleted, and data from recent extraction methods, such as hydraulic fracturing and tar sands extraction, show that industry is increasingly lurching towards the net energy cliff. Such action on the part of some of the largest and most commercially successful trans-national corporations may only be understood as the logical result of the extreme energy process ${ }^{46}$ - there simply are not enough easier-to-extract resources available. ${ }^{47}$

Despite the obvious negative implications of these developments, the process shows no sign of stopping, but continues towards the precipice at an ever-increasing rate, fuelled by ever-increasing levels of energy consumption. Perpetuated by the global economic 'growth' fixation, ${ }^{48}$ increasing amounts of energy are consumed each year, ${ }^{49}$ driving the process over the edge. Of course, industry is not willing to halt the process ${ }^{50}$ as intense demand further 
pushes up the price of energy, ${ }^{51}$ allowing extraction to remain economical - as long as enough resource is extracted at each site and the price stays high. The result is that higher energy consumption leads to faster resource depletion, which in turn results in the acceleration of the extreme energy process. Within this neoliberal economic context of increasing demand and profit potential the results of extreme extraction techniques, ${ }^{52}$ and the consequences of continuing the process, are easily trumped in the interest of shortterm profiteering and 'energy security'. Indeed, as Stephanie Malin notes, neoliberal 'normalization' of unconventional energy extraction emerges most saliently regarding environmental outcomes and economic development. ${ }^{53}$ Despite the prospective consequences of reaching our limits to growth, and with considerable evidence demonstrating a strong correlation between extraction effort and damage to both society and the environment, the extreme energy process continues to accelerate with potentially disastrous consequences. $^{54}$

The depth of connections already established between the extreme energy process and the 'minimally good life' illustrates the otherwise overlooked insidious nature of this insistence upon striving towards the energy precipice. Human rights violations due to climate change and the release of pollutants are yet another side effect of humanity's dependence on fossil fuels that grows in magnitude with each decade. The tropics and subtropics have seen droughts increase in intensity and duration since the $1970 \mathrm{~s},{ }^{55}$ and diseases such as malaria are affecting larger portions of the population. ${ }^{56}$ Two hundred thousand deaths in the US each year result from air pollution, ${ }^{57}$ while a heat wave across Europe in 2003 (most likely resulting from global climate change) ${ }^{58}$ left roughly 30,000 people dead. ${ }^{59}$ There is strong evidence to suggest that the worst consequences of anthropogenic climate change on human rights have not yet been felt. As predicted in The Limits to Growth. ${ }^{60}$ the effects of climate degradation will rapidly increase with temperature throughout the twenty-first century, ${ }^{61}$ resulting in large-scale deaths across Europe due to heat stroke, ${ }^{62}$ worsening droughts across continents, ${ }^{63}$ further loss of food and water, and a potential, eventual, extinction-level event for humanity if global emissions are not reduced in accordance with the latest climate science modelling. Such events, along with resulting unrest, wars and mass migrations, ${ }^{64}$ threaten people's rights to life and health worldwide.

The rush to scrape the bottom of the fossil fuel barrel is thus creating a veritable perfect storm for current and future human rights abuses. As resources become scarcer our scramble to use them grows, increasing the political prioritisation of fossil fuel extraction over ecosystems, human health and security; while increasing demand also ensures that such resources will run out sooner, which in turn will result in further human rights violations as food, health care and other basic needs are no longer met, to say nothing of the abuses to human security which would also necessarily increase. These violations will most likely increase exponentially as resources are depleted - at least, that is, until the sharp population decline predicted in The Limits to Growth occurs. ${ }^{65}$

\section{'Fracking' as the latest step in the process}

In addition to the infamous "tar sands ${ }^{96}$ in Alberta Canada, the march towards the net energy cliff is arguably spearheaded in the West by the most recently developed family of extreme energy extraction methods known as 'fracking', a colloquial expression which usually refers to the extraction of shale gas, CBM (coal-bed methane) and 'tight oil'. The term, however, has become somewhat loaded, such that it is necessary to outline the contrasting uses and define the senses in which it is invoked in this article. In 
public discourse about 'fracking' different sides often talk past each other, due to very different understandings of what the issues are, and differing definitions of the term itself. These differences fall along a spectrum that can be understood in terms of the interests of the parties involved.

Exploitation of unconventional oil and gas is a new, more extreme form of fossil fuel extraction, targeting much less permeable rock formations than previous conventional oil and gas extraction. It is characterised by the drilling of dense patterns of, usually horizontal, wells (up to eight per square mile or more) in conjunction with other more intense processes such as hydraulic fracturing and de-watering. Different rock formations can be targeted, such as shale (shale gas and oil) and coal (CBM), but the negative impacts on the environment and society are very similar. For many local people affected, 'fracking' has come to mean petroleum extraction companies turning up where they live and coating the area in hundreds or thousands of well-pads, compressor stations and pipelines alongside large volumes of truck traffic with some likening it to an 'invasion' and 'occupation', ${ }^{67}$ bringing with it a large variety of negative consequences for them and their environment.

The word 'fracking', however, is derived from 'fraccing', a much more narrowly defined industry slang for 'hydraulic fracturing', one particular stage of unconventional petroleum (oil or gas) extraction. A scaled-up form of hydraulic fracturing (high volume), involving injecting fluids under high pressure to crack the rock, is often used to release hydrocarbons during unconventional oil and gas extraction. The communities living with the consequences of unconventional oil and gas extraction are mainly concerned with the impact it has on them and their environment. Unconventional oil and gas extraction is a complex process, involving pad construction, well drilling, casing, stimulation (often including but not limited to hydraulic fracturing), extraction and transport, along with well plugging and abandonment (or failure to do so). All these stages have a consequent impact on their local environment and, due to the fact that fracking requires so many more wells covering much larger areas, these impacts mount up to a far greater extent than for conventional extraction and production.

In an era of peaked conventional supplies, ${ }^{68}$ extractive industries are principally concerned with finding new fossil fuels to extract in order to ensure continued profits, the cumulative impacts of which are likely to be seen as little more than simple 'externalities' for the companies involved. Focused as they are on getting gas and oil out of the ground, regardless, the industry and their government supporters are concerned to utilise the technologies for just that. Moreover, they work on a drilling site by drilling site basis, and the cumulative impact of the whole process seems to be of little concern. It is also useful in their public relations to focus on micro details rather than the macro picture, and a narrow definition of 'fracking', as simply hydraulic fracturing, helps promote the impression that fracking is simply conventional extraction plus hydraulic fracturing, rather than an entirely different process with very different impacts. Quite possibly one of the reasons the term 'fracking' has become synonymous with unconventional oil and gas extraction more generally lies in the choices made by the industry in their early promotional pitches to investors. Indeed, in the early part of the last decade, it seems that to raise funds for exploration a simple technological explanation was preferred when pitching to non-experts. The industry chose to focus attention on hydraulic fracturing as the key ingredient out of a complex array of technological processes. It is not difficult to understand why the idea of a new, high-tech well completion method, 'massive slick-water hydraulic fracturing', which was going to single-handedly revolutionise the industry by allowing access to a wealth of previously untapped resources, was an attractive sales pitch to investors. A more accurate view of unconventional oil and gas, as requiring much more effort, drilling greater numbers of 
much more expensive wells in order to produce much less oil/gas, does not sound like such an attractive proposition in comparison. It is therefore unsurprising that the terminology used to describe the industry (and the understanding of the issues involved) has become somewhat skewed by this initial spin.

Given that this article deals with the impact of unconventional extraction on people and the environment from a human rights perspective, the issues raised are the wider ones surrounding the overall effects of the entire more-intense extraction process, rather than ones specific to particular technologies the industry may or may not use. For this reason it is far more appropriate to use this wider definition of 'fracking', rather than the more narrowly defined industry slang that has the effect of limiting discourse to just the narrow technical process of hydraulic fracturing itself, as if it could occur in an isolated vacuum without its necessary production infrastructure. Even so, it should still be acknowledged that since there are often significant levels of confusion surrounding the use of the term, the particular understanding being used should always be defined. Thus, to be clear, in this article 'fracking' is being used in its wider sense to include all of the required industrial elements of hydraulic fracturing, from huge quantities of water, to compressor stations, truck traffic and waste disposal.

In the countries where 'fracking' development has taken place it has been controversial and divisive. Supporters of unconventional gas development often claim that it reduces gas prices, creates employment opportunities and provides 'energy security', all the while producing lower carbon emissions than coal. Its detractors often contest all such claims, usually pointing to contrary data emerging from the US and Australia. Indeed, in numerous studies from both countries, local communities most affected by developments often cite considerable negative impacts on the environment and human health, including groundwater contamination, air pollution, radioactive and toxic waste, water usage, earthquakes, methane migration and the industrialisation of rural landscapes, ${ }^{69}$ the cumulative effect of which has led to calls for the United Nations Human Rights Council (HRC) ${ }^{70}$ to condemn fracking as a threat to basic human rights, particularly the rights to water and health. Fracking development is fast becoming a human rights issue. ${ }^{71}$

\section{A need for human rights impact assessments}

The United Nations Environment Programme (UNEP) has issued a "Global Alert" ${ }^{72}$ on the issue of fracking development, warning of significant environmental risks to the air, soil and water (contamination and usage competition); ecosystem damage; habitat and biodiversity impacts; and fugitive gas emissions - which will endanger carbon reduction targets. In terms of public health, $\mathrm{UNEP}^{73}$ warned of risks of pipeline explosions; release of toxins into air, soil and water; and competition for land and water resources needed for food production and that unconventional gas would likely be used in addition to coal rather than being a substitute ${ }^{74}$ and would thus pose a threat to the development of sustainable economies.

Most of the academic papers on the impacts of fracking have focused on such issues as the macroeconomic benefits of a 'shale gas revolution', the 'green' credentials of shale gas, ${ }^{75}$ and the levels of environmental impact and responsibility for it. ${ }^{76}$ The few human impact investigations undertaken have come from investigative journalists, ${ }^{77}$ small nongovernmental organisations (NGOs) ${ }^{78}$ and documentary filmmakers. ${ }^{79}$ While valuable, such studies have been limited in scope and were not comparative. Recently anthropologists and sociologists have started to document the social and political discourses of fracking and the surrounding social conflicts in discreet Australian communities ${ }^{80}$ and perceptions of 
risk and opportunity in American communities, ${ }^{81}$ but they predominantly engage in discourse and perception analysis rather than invoking an impact-based analysis. A recent sociological study of the UK context takes a similar discourse analysis approach, albeit at an earlier stage of development, i.e. the exploration stage. ${ }^{82}$ Though such studies highlight the relevant priorities - and possible weaknesses - of arguments for and against fracking, they do not utilise an interdisciplinary approach that would engage with scientific findings that speak to an empirical reality beyond individuals' 'perceptions', nor do they systematically interrogate how individual perceptions and behaviours are affected by wider social structures and institutionalised power.

Taking a broader, more structurally aware approach, a recent study has shown that 'neoliberal logic' has led stakeholders to self-regulate their behaviour in order to facilitate fracking, by seeing its current role in rural industrialisation, its potential environmental and health outcomes, and its economic outcomes as part of a 'new normal' ${ }^{83}$ The consequences of this normalisation of loss of agency therefore raises fundamental questions about the ability of communities to resist extractive operations and make informed choices about the sources of their energy. Green criminologists have also called for a more theoretically robust approach to the study of ecological harms and crimes. ${ }^{84}$ A recent study by Shelley and $\mathrm{Opsal}^{85}$ of the social and ecological impacts of energy extractive practices on local communities implies that green criminologists are starting to investigate this issue, documenting not only illegal actions but also processes and outcomes that are 'harmful' to humans, animals and the environment. In a recent paper de Rijke noted:

the extraordinary expansion of the unconventional gas industry has ... led to questions about social power and the rights of individuals and local communities, the role of multinational corporations in politics and rural service provision, as well as related questions regarding fundamental processes of democracy, capitalist economies and social justice ${ }^{86}$

while the

close relationship between governments and powerful multinational corporations brings to the fore questions about political influence and human rights. ${ }^{87}$

Thus, to address these 'important conundrums', de Rijke advocated further academic research into fracking from multiple perspectives, including social impact assessments. Given the weight of evidence of human impacts that is emerging from countries with a mature fracking industry, such as the US and Australia, we suggest it is time to meet de Rijke's call through the human rights lens, i.e. the creation of comprehensive interdisciplinary human rights impact assessments (HRIAs) of fracking.

The last ten years has seen a growth in HRIAs that have been developed by a variety of actors as an extension of, or improvement on, social impact assessments (SIAs), which in turn developed from environmental impact assessments (EIAs). Recent academic literature on HRIAs ${ }^{88}$ has identified a number of distinct advantages of such assessments over broader SIAs. With recent UN-based developments regarding the human rights due diligence obligations for companies, ${ }^{89}$ particularly in the extractive industries, the HRIA methodology is valuable because it uses a set of norms and standards that are based on shared values and, therefore, represents a solid normative foundation on which to base impact assessments. ${ }^{90}$ Second, human rights represent legal obligations of states, rather than simply aspirations, and so HRIAs may compel duty-bearers to act to protect the rights of rights-holders. ${ }^{91}$ Third, HRIAs require a disaggregation of impacts to ensure that the 
effects on vulnerable groups are identified, such as women, children and indigenous groups. The human rights approach also encourages respect for stakeholder rights to information, participation, transparency and accountability ${ }^{92}$ and a commitment to improving the quality of life of people and communities ${ }^{\prime 93}$ and a desire to influence policy and practice to that end. The methodological focus of a HRIA is an evidence-based evaluation of commitments made by a state and the actual ability of individuals, groups and communities in a country to enjoy these rights. HRIAs provide (intergovernmental) organisations, governments and companies with instruments to better focus their human rights efforts; and civil society, community activists and NGOs can use them as an analytical and lobbying tool. A HRIA can be done before the activity takes place (ex ante), or after the activity has taken place (ex post).

What is missing, both from academia and the world of public policy are impartial interdisciplinary human rights-based investigations of a range of effects, impacts and changes brought on by fracking projects and experienced by individuals, families and communities in countries with a developed industry, such as Australia and the US, so as to better understand actual and potential human rights impacts for future affected communities in those countries and in countries at pre-production stages. At the same time research must include data collected from sites with different levels of industry maturity as evidence from the US has shown that support for fracking reduces with experience of cumulative impacts. ${ }^{94}$ It is vital that this research commences forthwith since many countries currently at various exploration stages (e.g. the UK, Poland, Romania, Botswana, South Africa and Argentina) are seeking to move to full production within the next five years and production is already beginning in some countries (e.g. China, India and Indonesia), while established producers will seek to expand when, and where, possible. This is all taking place without adequate research on the social and human rights impacts of such development and how these relate to the environmental impacts. Indeed, the next five years represent a crucial window of opportunity for stakeholder communities, civil society organisations and NGOs to meaningfully engage with those proposing fracking development; impartial, community-based HRIAs will greatly aid this endeavour.

In the balance of this article we demonstrate that there are at least ten areas of concern that would provide key 'indicator' data for such assessments due to their inherent connection with the fracking process and its social and political context. These areas are: water, air, land, health, freedom of peaceful assembly, freedom of expression, liberty and security of the person, right to a fair trial, right to respect for the private and family life, and anthropogenic climate change.

Many of the negative effects of fracking have revolved around these key issues, each of which has a legal basis in human rights and an obvious connection to Nickel's 'minimally good life'. Thus, an examination of each topic is essential to making the prima facie case for assessing fracking's human rights impacts in an interdisciplinary manner that goes beyond existing 'perception' studies to include additional empirical data, often from scientific sources.

\section{Water}

One of the most contentious and widely publicised environmental, and we would argue human rights, issues connected with fracking is the water impact: groundwater contamination, water use and contaminated water waste disposal. Shale gas production is a highly water-intensive process, with a typical single well requiring around five million gallons of water, and an average well-pad cluster up to 60 million gallons, to drill and 
fracture, depending on the basin and geological formation. ${ }^{95}$ The vast majority of this water is used during the fracturing process, with large volumes of water pumped into the well with sand and chemicals to facilitate the extraction of the gas; the remainder is used in the drilling stage, with water being the major component of the drilling fluids. Once that water is used by the industry it is no longer a useful resource for society. While increasing quantities of water are being recycled and reused in the US, freshwater is still used in large quantities for the drilling operations as 'produced' water is more likely to damage the equipment and reduce the chance of a 'successful well'. The industry's requirements ${ }^{96}$ for such quantities of freshwater are clearly a serious concern in water-scarce regions of the world and in places with high cumulative demand for water.

In the case of CBM extraction the major water use is the dewatering of the coal seams, in order to allow the gas to flow. This involves pumping large quantities (hundreds of thousands of litres per day) of water out of each well. The overall effect of pumping out such large amounts of water, when multiplied by potentially thousands of wells in any given region, is usually to dramatically lower water tables in the area, since freshwater aquifers nearer the surface tend to drain down into the coal seams when water is removed from them. For instance, the Queensland Water Commission predicts a massive water table drop of $700 \mathrm{~m}$ in some areas due to $\mathrm{CBM}$ extraction. ${ }^{97}$ So while the mechanisms are very different, the overall impacts of shale and CBM extraction on water availability are just as serious. Such demand pressures are already being felt in areas of the US and Australia, leading to pressure on water sources and competition for withdrawal permits. ${ }^{98}$

The large quantity of water used by the fracking industry is but one of many serious concerns. The contamination of groundwater sources, ${ }^{99}$ from failure in the well casing over time, ${ }^{100}$ what industry refers to as 'zonal isolation' failure, is a very serious issue across regions that have seen considerable fracking development to date, and has duly featured as a central public relations battleground for industry and pro-fracking governments. Even so, arguably the most concerning issue with fracking's use of water is the issue of produced/waste water treatment and disposal, often simply referred to as 'waste water management'. And yet, the risks in this regard go well beyond the concerns of corporate risk minimisation. Indeed, the whole process of dealing with fracking's waste water is a highly risky business for local populations and the environment, with considerable risks of water or soil contamination from surface leaks and spills. ${ }^{101}$ But perhaps the most concerning issue with waste water is that it can contain significant amounts of radioactive material $^{102}$ due to the 'naturally occurring hypersaline brines associated with the formations targeted for natural gas production'. ${ }^{103}$ For instance, radium has been found to be building up in rivers downstream of shale gas waste discharge points in Pennsylvania, ${ }^{104}$ while a company has been fined for contaminating an aquifer with CBM (termed coal seam gas (CSG) in Australia) waste containing uranium in New South Wales, Australia. ${ }^{105}$

Summarising much of the data, a recent landmark US study by Vengosh et al. argues that the overall risks posed by fracking development for water are fourfold (a similar, though subtly different list could be produced for $\mathrm{CBM}^{106}$ extraction) ${ }^{107}$ :

- Contamination of shallow aquifers in areas adjacent to shale gas development through stray gas leaking from improperly constructed or failing gas wells.

- Contamination of water resources in areas of shale gas development and/or waste management by spills, leaks or disposal of hydraulic fracturing fluids and inadequately treated wastewaters. 
- Accumulation of metals and radioactive elements on stream, river and lake sediments in wastewater disposal or spill sites, posing an additional long-term impact by slowly releasing toxic elements and radiation to the environment in the impacted areas.

- Reduction of water supply through withdrawals of valuable fresh water from dry areas and overexploitation of limited or diminished water resources for shale gas development.

The human right to water was first recognised within the UN system by the Committee on Economic, Social and Cultural Rights through their 2002 General Comment 15, which located it implicitly in the rights to an adequate standard of living and to the highest attainable standard of health set out in Articles 11 and 12 of the International Covenant on Economic, Social and Cultural Rights (ICESCR), respectively. In 2005, the Special Rapporteur of the Sub-Commission on the Promotion and Protection of Human Rights issued draft guidelines for a resolution on the right to drinking water and sanitation, ${ }^{108}$ which were adopted by the Sub-Commission in 2006 as the Guidelines for the Realization of the Right to Drinking Water and Sanitation. The HRC followed the guidelines with a request for the High Commissioner for Human Rights to study the scope and content of human rights obligations related to access to safe drinking water and sanitation under current international human rights instruments. ${ }^{109}$ The results of the study were presented to the HRC in 2007 and included the High Commissioner's recommendation that ' $\ldots$ it is now time to consider access to safe drinking water and sanitation as a human right'. ${ }^{110}$ An independent expert on the issue of human rights obligations related to access to safe drinking water and sanitation was established by the HRC in 2008, and in July 2010 the UN General Assembly adopted resolution 64/292 recognising the 'right to safe and clean drinking water and sanitation as a human right this is essential for the full enjoyment of life and all human rights' ${ }^{111}$ In March 2011 the independent expert's mandate was extended and the title altered to Special Rapporteur on the Human Right to Safe Drinking Water and Sanitation. ${ }^{112}$

Though the right to clean drinking water and sanitation has now been affirmed by the General Assembly and the HRC, ${ }^{113}$ there is no explicit international instrument on the right. Rather, the HRC has defined the human right to water and sanitation to derive from the right to an adequate standard of living and found it inextricably related to the rights to health, life and human dignity. Additionally, numerous international instruments include the right to water and sanitation. The 1979 Convention on the Elimination of Discrimination Against Women $(\mathrm{CEDAW})^{114}$ is the earliest such example, stating the right of women to water and sanitation as elements of the right to adequate living conditions. Subsequently, International Labour Organization (ILO) Convention 161 of $1985^{115}$ referred to the right of workers to sanitary installations, the 1989 Convention on the Rights of the Child (CRC) stated the right of children to clean drinking water, ${ }^{116}$ both the 1990 African Charter on the Rights and Welfare of the Child and the Protocol to the African Charter on Human and Peoples' Rights (ACHPR) on the Rights of Women in Africa ${ }^{117}$ include the rights to safe drinking water, and, most recently, the 2006 Convention on the Rights of Persons with Disabilities (CRPD) includes the rights to clean water services as a subset of the right to social protection. ${ }^{118}$

With such evidence of wide international acceptance of the human right to water and sanitation, and considering the place of this right within the context of a 'minimally good life', it is thus appropriate to consider access to clean water and sanitation a fundamental human right and necessary to consider the impact of the fracking industry on that right. Despite its widespread use in the US for over a decade, hydraulic fracturing has only 
recently been scrutinised to determine if and what its effects are on human rights. Under the special procedures of the HRC, the Special Rapporteur on the Human Right to Safe Drinking Water and Sanitation, Catarina de Albuquerque, concluded her 2011 mission to the US by outlining serious concerns over the effect of a range of polluting activities associated with the hydraulic fracturing process, observing a distinct: 'policy disconnect ... between polluting activities and their ultimate impact on the safety of drinking water sources. The absence of integrated thinking has generated enormous burdens, including increased costs to public water systems to monitor and treat water to remove regulated contaminants and detrimental health outcomes for individuals and communities. ${ }^{119}$ While a comprehensive report on the effects of hydraulic fracturing on water quality is expected from the US Environmental Protection Agency late 2015, ${ }^{120}$ there have recently been other, smallerscale studies revealing water contamination due to fracking processes. Ingraffea et al.'s review of compliance reports from conventional and unconventional oil and gas wells drilled in Pennsylvania between 2000 and $2012^{121}$ reveals that casing/cement impairment is six times more likely to occur in shale gas wells than in conventional wells. Such flaws may result in cases of subsurface gas migration into the water supply, as has already occurred in the state. Indeed, published data demonstrate evidence of "contamination of shallow aquifers with hydrocarbon gases ... contamination of surface water and shallow groundwater from spills, leaks, and/or the disposal of inadequately treated shale gas wastewater ... [and] accumulation of toxic and radioactive elements in soil or stream sediments near disposal or spill sites ...' from hydraulic fracturing throughout the US. ${ }^{122}$ Qualitative data from Colorado have further revealed complaints of water contamination from residents living near fracking sites that are often intentionally misunderstood, assigned a different cause, or diluted by state regulatory bodies. ${ }^{123}$ Recently the Pennsylvania Department of Environmental Protection disclosed details of 243 cases in which fracking companies were found by state regulators to have contaminated private drinking water wells in the last four years. ${ }^{124}$ Cumulatively, these reports indicate likely impairment of the right to water for residents living near fracking sites.

\section{Air}

A major, and often under-appreciated, impact of fracking is air pollution. Despite water issues gaining the majority of press and public attention, it is becoming clear that for most people reporting health problems associated with fracking, air pollution is far more likely to be the initial cause. ${ }^{125}$ This is because air pollution will be present as soon as drilling begins and it is much harder to avoid exposure to it. In comparison, the effects of water pollution take much longer to emerge and it can take years for well casings to degrade causing the wells to leak. Also, in the West at least, using alternative sources once a problem is spotted can mitigate water contamination issues. A particularly serious air pollutant produced by fracking is ozone, a powerful lung irritant that contributes to asthma and other breathing disorders, and which can form as a result of reactions between leaking methane and nitrogen oxides emitted from exhausts of diesel-powered equipment. Areas with previous pristine air such as the Upper Green River Basin in Wyoming are now seeing ozone levels spiking higher than those seen in Los Angeles, with people complaining of watery eyes, shortness of breath and bloody noses. ${ }^{126}$ Ground-level ozone is a component of smog and a costly, high-priority public health risk. Ozone exposure can cause irreversible damage to the lungs and significantly increase the chance of premature death.

In addition, numerous other chemicals present in natural gas at the well-head (including hydrogen sulphide, benzene ${ }^{127}$ and other volatile hydrocarbons) can adversely, and 
seriously, affect air quality. Moreover, we need to consider the whole unconventional gas extraction and production process when considering the effects of such developments. In terms of impacts on localised air quality, emissions from trucks, compressors, pumps and other equipment used in the drilling and production process contain a complex mixture of benzene, toluene and xylene as well as other volatile organic compounds (VOCs). ${ }^{128}$ Dust levels must also be considered: drilling activities and associated site traffic generate significant levels of dust while the small particle-size silica sand used in hydraulic fracturing can cause silicosis, an incurable lung disease, and increases the risk of lung cancer. ${ }^{129}$

Fracking operations release VOCs 'at each stage of production and delivery' ${ }^{130}$ and while ozone is usually associated with automobile exhaust emissions, fracking generates it when VOCs in wastewater 'ponds' evaporate and come into contact with well site vehicle and generator diesel fumes. ${ }^{131}$ VOCs and ozone pollution have been detected at dangerous levels at fracking sites in the US across Colorado, Wyoming and Utah. Indeed, a major study in North-Eastern Colorado ${ }^{132}$ found exceptionally high levels of VOCs in the air and traced the chemical signature of around $55 \%$ of them directly back to gas and oil operations. Over significant periods in 2011, the level of ozone pollution in rural Wyoming's gas drilling areas exceeded that of Los Angeles and other major cities, and with an upper limit of 116 parts per billion, exceeded the US Environment Protection Agency's healthy limit of 75 parts per billion. ${ }^{133}$ Uintah County, Utah, an area with some of the highest-producing oil and gas fields in the country, has experienced dangerously high levels of VOCs and resultant ozone for over five years: the amount of VOCs released in 2013 in Uintah County alone was calculated as the equivalent of emissions from 100 million automobiles. ${ }^{134}$

A University of Colorado Denver, School of Public Health study documented dangerous airborne levels of benzene ${ }^{135}$ - known to cause multiple forms of leukaemia and other blood disorders - near hydraulic fracturing operations. ${ }^{136}$ The study found elevated risks of cancer for residents within half a mile of a drilling site. In another study focussing on Northern Texas, ${ }^{137}$ ambient air testing near gas drilling operations found excessive amounts of many toxic chemicals, including benzene and carbon disulphide, an extremely high-risk pollutant, possessing what the Texas Commission on Environmental Quality called 'disaster potential'. ${ }^{138}$ These chemicals were traced back to the drilling operations, as the testing location had 'virtually no heavy industry other than the [natural gas] compression stations'.'139 Another report identified significant amounts of over 40 health-harming chemicals in the air near drilling sites in Colorado and although none were detected at levels above United States Environmental Protection Agency (EPA) limits, that study and others have noted that the EPA's ambient air quality standards may not be strict enough. ${ }^{140}$ Health standards often do not fully account for long-term health effects of chemicals and enhanced risks to vulnerable populations ${ }^{141}$ such as pregnant women, young children and the elderly. ${ }^{142}$

A University at Albany Institute for Health and the Environment study ${ }^{143}$ recently identified eight highly toxic chemicals in air samples collected near fracking and associated infrastructure sites across five states: Arkansas, Colorado, Pennsylvania, Ohio and Wyoming. Chemicals detected included two benzene and formaldehyde (proven human carcinogens) and hexane and hydrogen sulfide (two potent neurotoxins). The study found that for 29 out of 76 samples, concentrations far exceeded federal health and safety standards, in some cases by several orders of magnitude. Moreover, in some instances highly elevated levels of formaldehyde were found up to half a mile from a wellhead. Indeed, in Arkansas, seven air samples contained formaldehyde at levels up to 60 times the level known to raise the risk for cancer. ${ }^{144}$ According to the study's lead author 'this is a significant public health 
risk ... Cancer has a long latency, so you're not seeing an elevation in cancer in these communities. But five, 10, 15 years from now, elevation in cancer is almost certain to happen. ${ }^{145}$

When considering the fundamental right to clean air (minimally, air that is free from harmful levels of pollution), as a necessary aspect of the 'minimally good life', it is necessary to first note that access to air - like water - 'was an entitlement so natural and fundamental that it was probably inconceivable that the continued availability of this access had to be guaranteed as a human right'. ${ }^{146}$ Accordingly, an explicit right to air is not found in any UN human rights instruments or special procedure. Despite this apparent international inattention to the right to clean air, numerous national and regional bodies have recognised the positive obligation of governments to ensure clean air for their populace, either as a component of other internationally recognised rights or as an aspect of the right to a healthy environment.

At the national level, the obligation of the state to protect its people from detrimental pollution has been affirmed in countries across the world. Some of the most explicit references to air pollution have come from Asia, as the Supreme Court of India, in Subhash Kumar v. State of Bihar (1991), stated that the right to life includes the right to pollution-free water and air. ${ }^{147}$ Additionally, the Human Rights Commission of Malaysia, a national human rights institution established by the Malaysian Parliament in 1999, has asserted that the right to liberty within the Malaysian Constitution obliges the government to provide clean air, based on their analysis of Malaysian national and case law. ${ }^{148}$ More generally, environmental rights, as such, are recognised in 92 state constitutions, spanning every continent, from Portugal to Mexico to Indonesia, Brazil to Madagascar to Russia. ${ }^{149}$ Even with such limited examples of a state-recognised right to clean air specifically, this conglomeration of national acknowledgement of the right to a clean environment demonstrates that the human right to air is broadly recognised, despite the absence of a UN mechanism.

Examining regional human rights law further reveals the general acceptance of a right to clean air, in so far as it is consistent with a general right to a healthy environment. Article 24 of the ACHPR expressly states the right of '[a]ll peoples ... to a general satisfactory environment favourable to their development'. ${ }^{150}$ In the Americas, the Additional Protocol to the American Convention on Human Rights in the Area of Economic, Social and Cultural Rights affirms in Article 11 that '[e]veryone shall have the right to live in a healthy environment', and that it is the state's obligation to 'promote the protection, preservation, and improvement of the environment'. ${ }^{151}$ Within Europe, the European Court of Human Rights (ECtHR) ruled that air pollution specifically could be a violation of the right to respect for home and private and family life in Lopez Ostra v. Spain (1994). ${ }^{152}$ The court has also found that denying access to fresh air contributes to degrading and inhumane treatment. ${ }^{153}$ In the case of Öneryildiz v. Turkey (2004), the ECtHR ruled that the government has a duty to protect private property from environmental risks, as an element of the right to the peaceful enjoyment of possessions. ${ }^{154}$ Thus, evidence within each of the three most prominent regional human rights legal systems suggests that there exists a general right to a healthy environment - which must arguably include the right to clean air.

Finally, while the UN system has not recognised the right to clean air as it has the right to water, connections between human rights and a healthy environment have recently been enhanced at the global level. The introduction of an independent expert on human rights and the environment in 2012 demonstrates the growing acceptance that '[a] safe, clean, healthy and sustainable environment is integral to the full enjoyment of a wide range of human rights, including the rights to life, health, food, water and sanitation'. ${ }^{155}$ More recently, the $\mathrm{HRC}$ has recognised that 'environmental damage has negative implications 
... for the effective enjoyment of human rights, in particular of the right to life, the right to the enjoyment of the highest attainable standard of physical and mental health, [and] the right to an adequate standard of living and its components ... ${ }^{156}$ On air quality specifically, the NGO Subcommittee on Poverty Eradication submitted, in a report to the UN Human Rights Council, that there exists an inherent right to clean air that should be universally enjoyed as a component of the right to 'life-sustaining natural resources'. ${ }^{157}$ As of 2012, $177 \mathrm{UN}$ member states recognise the right to a healthy environment either "through their constitution, environmental legislation, court decisions, or ratification of an international agreement ... ${ }^{158}$ Whether or not the right to clean air is explicitly stated, it is vital to a healthy environment, the rights to life and health (discussed below) and many others, in short it is vital to the minimally good life. Thus, the current and potential effects of fracking upon air quality represent not just an environmental threat, but also a threat to the enjoyment of human rights.

\section{Land}

Fracking production has a considerable visual and physical impact on local landscapes. Indeed, fracking involves cluster well-pads, compressor stations, new site access roads, waste water containers/ponds and high-volume site traffic. Industry and government denials aside, the empirical reality of fracking developments is a considerable industrialisation of rural areas. ${ }^{159}$ Land can also be impacted through water, air or soil pollution as we have seen above, along with damage to livestock, vegetation and wildlife ${ }^{160}$ and damage associated with fracking-induced seismic activity. ${ }^{161}$ While earthquakes may not be very serious for local properties, although some have certainly been damaged, they can damage the cement well casing, increasing the likelihood of what the industry calls 'zonal isolation failure' - in other words well casing failure - as happened already at the exploration stage in the UK at Cuadrilla's Presse Hall test site in Lancashire ${ }^{162}-$ and which could result in methane leaks and groundwater contamination.

Colorado has seen significant direct and indirect effects on wildlife, including population declines and direct mortality, in gas development areas and recent discoveries of new oil reserves and changing industry technology have dramatically altered the course of development as well as the landscape of the state. ${ }^{163}$ In the mountainous regions of the Marcellus shale region fracking drilling leads to soil ground erosion, and loosened sediments quickly enter surface streams, contaminating cold-water fish habitats and drinking water sources. ${ }^{164}$ Even so, beyond these issues, perhaps the impact that will draw the most attention from local residents is the likely impact on local property values. As US researcher Richard Heinberg writes 'the various forms of land damage from fracking often result in decreased property values, making resale and farming difficult, and also making it harder to acquire mortgages and insurance. Properties adjoining drilling sites are often simply unsellable, as no one wants to live with the noise, the bad air, and the possibility of water pollution. 165

These impacts will of course multiply with each new development instigated in response to the short production cycle of the average fracking cluster. Indeed, fracking requires 'heroic rates ${ }^{\text {, }} 166$ of drilling to maintain production levels, and therefore enormous numbers of drilling sites. Fracking also impacts land far from drilling sites as it requires key material inputs such as sand - which itself needs to be mined and is used as a proppant (to hold hydraulic-induced fractures open). ${ }^{167}$ For example, fracking in Pennsylvania, Texas and North Dakota uses sand mined in Wisconsin, Minnesota and Iowa, which itself destroys farmland, impacts wildlife and degrades waterways, while tiny silica particles dislodged by 
mining, when taken up by winds, can result in higher rates of silicosis and cancer in local populations. ${ }^{168}$

In this context, the right to land can be viewed as the right to land free from severe ecological destruction and its negative effects upon human health and property values. This right, as a human right threatened by fracking, is comprised of the rights to respect for privacy, the family, and home, and protection of property - both of which have been legally established in numerous national, regional and international legal instruments. The 1966 International Covenant on Civil and Political Rights (ICCPR) includes the right not to be 'subjected to arbitrary or unlawful interference' to one's 'privacy, family, home or correspondence'. ${ }^{169}$ This right is also found in the European Convention on Human Rights (ECHR), ${ }^{170}$ the American Convention on Human Rights (ACHR), ${ }^{171}$ and the Arab Charter on Human Rights. ${ }^{172}$ Within the European context especially, this right to privacy, family and home has been used in cases of environmental degradation before the ECtHR. Although in most cases - relevant to the discussion of fracking's impact on the land - the court found no violation of this right, it did assert that violation was possible due to environmental destruction that directly affects human well-being (Kyrtatos v. Greece (2003)), ${ }^{173}$ damage to a home by nearby industry (Dubetska and Others v. Ukraine (2011)), ${ }^{174}$ or excessive levels of noise and dust (Martinez Martinez and María Pino Manzano v. Spain (2012)). ${ }^{175}$ Such findings are largely related to the right to protection of property, found in the Protocol to the ECHR, ${ }^{176}$ the ACHR, ${ }^{177}$ the ACHPR, ${ }^{178}$ the Arab Charter on Human Rights, ${ }^{179}$ in addition to numerous national constitutions. ${ }^{180}$ The ECtHR case of Flamenbaum and Others v. France $(2012)^{181}$ highlights the connection between these two rights as the court asserted that a drop in the market value of property, due to industry activities that could violate the right to privacy, the family and home, would be a violation of the right to protection of property. ${ }^{182}$ Therefore, when the rights to privacy, family, home and protection of property are read to include protection from pollution, environmental harm that affects human well-being, and damage to the home - including protection from arbitrary property devaluation due to nearby industrial activities - it is apparent that the effects of fracking on the land are capable of legally violating human rights.

\section{Health}

While scientific studies on the health impacts of fracking are still in their relative infancy, partially due to the time lag between environmental impacts and provable human health consequences, there is an emerging body of literature and growing awareness of recurring health defects found in residents living near fracking sites. ${ }^{183}$ The recently publicised Texas lawsuit by Robert and Lisa Parr against Aruba Petroleum, in which a jury awarded the family $\$ 3$ million, was based on the health effects they experienced following the arrival of fracking to their community. The Parrs complained of nosebleeds, vision problems, nausea, rashes and blood pressure issues ${ }^{184}$ - symptoms similar to those which have been reported near drilling sites in Colorado, ${ }^{185}$ Pennsylvania ${ }^{186}$ and other unconventional natural gas operations. ${ }^{187}$

Recent reports have also noted connections between maternal proximity to unconventional drilling sites and birth defects, including congenital heart defects, neural tube defects and low birth-rates, though these studies again lack the robust and comprehensive nature required to find a causal link between fracking-related pollution and health impairments. ${ }^{188}$ Despite this, the quantity of studies showing correlations between fracking and health problems is rising fast, with people living near fracking wells in Pennsylvania more than twice 
as likely to report upper-respiratory and skin problems. ${ }^{189}$ Serious ailments have been reported by families living in close proximity to drilling operations of the Eagle Ford Shale in South Texas, ${ }^{190}$ and increases in coughs, chest tightness, rashes, difficulty sleeping, joint pains, muscle pains and spasms, nausea and vomiting, spontaneous nose bleeds and skin irritations have been observed among residents living near CBM wells in Tara, Queensland. ${ }^{191}$

These reports are also deeply concerning for people living in countries at the exploration stage, especially where the authorities mean to protect public health in the development process but fail to take on board the latest peer-reviewed health studies. Indeed, for those UK residents living near proposed fracking sites, such as Preston New Road and Roseacre in Lancashire, Public Health England's (PHE) 25 June 2014 report was so inadequate in its coverage that there is some suggestion that it amounted to 'gross scientific misconduct'. ${ }^{192}$ A robust interdisciplinary human rights-based investigation seeking health indicator data would go well beyond PHE's meagre review of just 25 publications, ${ }^{193}$ up until their arbitrary cut-off date of December 2012, as there have been over 90 relevant reports published since. Many of these reports were considered in the New York State Department of Health's far more comprehensive report, which was instrumental in New York State recently issuing a moratorium on all fracking development on the basis that the public health risks were too great. $^{194}$

The various aspects of fracking's ecological footprint holistically demonstrate the potential for environmental rights violations to reach a severity capable of abusing the human rights to health and life. These rights, enshrined in numerous national and international instruments, including the International Bill of Rights, have been defined broadly by the UN and other bodies to include rights related to ecological preservation. ${ }^{195}$ The right to health is 'an inclusive right', comprising not only the right of access to health care but also the right to reasonable protection from detriments to health, such as 'access to safe and potable water and adequate sanitation' (see above) and to a healthy natural environment. ${ }^{196}$ The right to life is, of course, intrinsically linked to the right to health, as human life may be endangered by environmental degradation severe enough to damage human health. ${ }^{197}$ The European Court of Human Rights has, for instance, ruled that a state may violate right to life by not informing residents of nearby potential environmental safety risks or by failing to enact practical measures to avoid those safety risks. ${ }^{198}$

In the following section we discuss the currently under-researched civil and political dimensions of proposed fracking development in a key emerging context: the UK's 'second dash for gas'. ${ }^{199}$ The research sought to explore official responses to anti-fracking protests in the UK, with specific reference to the police response to anti-fracking protests. The discussion refers to civil and political rights that are all recognised in the UK's 1998 Human Rights Act (HRA), the ECHR and the ICCPR. These encompass the right to freedom of peaceful assembly, the right to freedom of expression, the right to liberty and security of the person, the right to a fair trial, and the right to respect for a private and family life. All of the rights discussed stem from the context of protest as a response to the proposed introduction of fracking in the UK, and are supported by primary research gathered through an online survey and interviews.

\section{Freedom of peaceful assembly}

Our UK-based primary research focussed on two exploratory (potential fracking) sites and their targeted protests: Balcombe in West Sussex ${ }^{200}$ and Barton Moss in Salford. ${ }^{201}$ Conflict arose at both of these locations due to the responses of Sussex Police and Greater 
Manchester Police (GMP), respectively, to these peaceful protests, conducted most commonly by protesters attempting to delay the delivery of equipment or chemicals by walking in front of the lorries delivering these items to the drilling site. The results of these actions by the police have been threats to, and arguable violations of, civil and political rights recognised in the HRA, ECHR and ICCPR. The right to peaceful assembly is articulated in Article 11 of both the HRA ${ }^{202}$ and the ECHR, ${ }^{203}$ and Article 21 of the ICCPR. ${ }^{204}$ All of these articles place restrictions upon how the right to freedom of peaceful assembly can be expressed, which are of immediate relevance to this discussion, seeking as they do to balance the right of the individual citizen with the legal powers of the state. In the context of this discussion, as a protest is an assembly, any action which prevents individuals from peacefully protesting is a violation of the right to peaceful assembly.

Article 11(2) of both the HRA and the ECHR detail how the only restrictions placed upon the freedom of peaceful assembly should be those 'prescribed by law', and are required 'in the interests of national security or public safety' or 'for the prevention of disorder or crime'. In addition, Article 11(2) in both the HRA and ECHR also states that ' $[\mathrm{t}] \mathrm{his}$ Article shall not prevent the imposition of lawful restrictions on the exercise of these rights by members of the armed forces, of the police or of the administration of the State'. Article 21 of the ICCPR gives less detail as to how the right to peaceful assembly should be controlled by the state, as it does not reference armed forces, police or state administration. The right to freedom of peaceful assembly in the ICCPR is therefore less restrictive than the expression of the same right in the HRA of the UK, drafted over three decades later.

The online survey gave valuable insight into the general experience of anti-fracking protestors, at least as far as can be gauged from a selective form of research. Of the 168 respondents, 98 had personal experience of direct action against fracking in the UK. Of that 98, 79 had either interacted with the police or witnessed interactions between the police and other protesters during that experience. Of those interactions, 56 (over 76\%) experienced or witnessed excessive use of force by members of the police, 64 (over $87 \%$ ) experienced or witnessed unnecessary use of force by members of the police, and 61 (over $83 \%$ ) experienced or witnessed unnecessary arrests. These figures provide, minimally, a generalisation of how the police responded to anti-fracking protests in the UK.

The overwhelming majority of both survey and interview respondents believed their right to freedom of peaceful assembly was prevented from being realised by the actions of police officers. The majority of comments below therefore illustrate the ways in which police failed to facilitate the right to freedom of peaceful assembly, as expressed in peaceful protest. This failure mostly involved the use of violence to inhibit individuals' ability to peacefully protest, but also extended to the removal of individuals from the protest site (without arrests being made) and unlawful arrests. Most interview respondents made reference to the fact that police were not facilitating any form of peaceful protest. With reference to Barton Moss, one respondent described how 'in terms of actual policing [... ] It was very difficult to run a campaign', due to GMP's control over the protestors' actions. $^{205}$ Another respondent described how they were removed from the Barton Moss protest by two police officers who 'were interfering with my right to protest' as 'they did stop me from actually demonstrating, ${ }^{206}$ illuminating the extent to which police were capable of forcibly preventing peaceful protest without making arrests. With regard to lorries, around which most protest activity revolved, one respondent described how police tactics changed between Balcombe, where one lorry was escorted at a time by the police, and Barton Moss: 'When we went to Barton Moss they decided to use the convoy system, bringing in anywhere between ten and fifteen trucks at a time [...] that way they undermined our ability to slow the process down. ${ }^{207}$ 
The change between Balcombe and Barton Moss was suggested as police altering their response to anti-fracking protest 'in light of what they learnt at Balcombe'. ${ }^{208}$ Aside from the changes to the escorting of lorries, a consistently referenced constant between the two protests was the use of violence by members of the police to prevent the realisation of the right to freedom of peaceful assembly through protest. In interactions with the police at both Balcombe and Barton Moss, interview respondents described how they were 'kicked and pushed and punched', 209 'pushed and shoved in the back', 210 'pushed off the road by the police', ${ }^{211}$ and 'shoved in the back repeatedly'. ${ }^{212}$ Police interactions were described as 'rough', ${ }^{213}$ 'ultra aggressive', ${ }^{214}$ and 'very, very aggressive', ${ }^{215}$ resulting in interactions in which 'bones got broken'. ${ }^{216}$ The interactions of police with other protestors was described as 'shoving people, pushing people, trying to knock people over, trying to get people on the ground', ${ }^{217}$ 'kicking their ankles', ${ }^{218}$ and 'deliberately kicking up the backs of legs' ${ }^{219}$ These data, gathered from interviews and alluded to in the experiences of survey respondents, indicate the primary method by which GMP and Sussex Police prevented the realisation of peaceful protest, supplemented by unlawful arrests, and is a far cry from police claims of acting 'professionally and fairly'. ${ }^{220}$

Further to police interference, indications of county council involvement in the controlling and dismantling of protests have appeared. The West Sussex County Council obtained a possession order for land where Balcombe protesters were camped, forcing them to relocate. Though the council provided a new area for the protest, it forbade camping on the site due to the safety risk posed by a nearby unlit road. ${ }^{221}$ The Salford City Council, covering the Barton Moss site, has been shown to meet regularly with the GMP and IGas during antifracking protests, sharing information and intelligence and discussing levels of acceptable police force. This is in contrast to the council's level of cooperation with protesters, as reportedly none of the councillors visited the protest site. ${ }^{222}$ To be sure, there have been significant issues with suppression of anti-fracking protests outside the UK. The fracking industry and governments in the US, Canada and Australia appear to often consider resistance by local people to be an 'insurgency', and anti-fracking groups, particularly in poorer or maginalised communities (HRIAs would need to disaggregate data in this regard), are routinely labelled as terrorists, ${ }^{223}$ subjected to psychological warfare operations, ${ }^{24}$ intimidation $^{225}$ and police violence. ${ }^{226}$

\section{Freedom of expression}

The right to freedom of expression is detailed in Article 10 of both the $\mathrm{HRA}^{227}$ and $\mathrm{ECHR}^{228}$ and Article 19 of the ICCPR. ${ }^{229}$ This freedom is understood in Article 10(1) of the HRA and the ECHR as the 'freedom to hold opinions and to receive and impart information and ideas without interference by public authority', and in Article 19(2) of the ICCPR as the 'freedom to seek, receive and impart information and ideas of all kinds [... ] either, orally, in writing or in print'. With relevance to the preceding discussion on the right to peaceful assembly, this freedom can be expressed in the form of protest. ${ }^{230}$ Although every instance in which police responses have restricted the right to peaceful assembly could also be discussed here, it will suffice to say that any unlawful restriction of protest through 'interference by public authority' can be considered a violation of the right to freedom of expression.

In addition, as indicated by the human rights legislation, the right to freedom of expression is concerned more generally with the imparting of information or ideas. One interview respondent made reference to banners outside the homes of residents on Barton Moss Lane, who lived in proximity to both the Barton Moss protestors' camp 
and IGas' exploratory drilling site. The interview respondent explained how the occupants of the buildings had made banners saying 'No shale' and 'No methane gas mining here'. ${ }^{231}$ These banners, although located on the private property of the residents, had prompted GMP to visit and request that the banners be removed - seemingly in contravention of the right to freedom of expression. As with police response to protest, the interference by public authority is explicit here: GMP's actions interfered with the ability of the residents to 'hold opinions' and 'impart information and ideas' through the medium of anti-fracking banners. If this request did not violate the right of the residents to freedom of expression then reference must be found within the domestic and international legislation for legitimate interference by public authority.

The HRA, ECHR and ICCPR all contain details as to how and why the right to freedom of expression may be curtailed by the representatives of the state. Article 10(2) of both the HRA and the ECHR state that this right 'may be subject to such formalities, conditions, restrictions or penalties as are prescribed by law', which are clarified as 'the interests of national security' and 'the prevention of disorder or crime'. Similarly, Article 19(3) of the ICCPR states that the right to freedom of expression 'may [ ... ] be subject to certain restrictions, but these shall only be such as are provided by law', which are, in Article 19(3), described as being 'For the protection of national security or of public order'. For the request by GMP not to have violated the residents' right to freedom of expression, the presence of the banners must be considered a threat to national security or public order, or their removal must be considered necessary to prevent crime. These three scenarios appear to be legally unfounded, unless the anti-fracking movement itself is considered a threat to 'national security'. The banners may have encouraged activity at the Barton Moss protest camp, but that would only prompt legal justification for their removal if said activity was considered to be a threat to public order, or to constitute a crime. As the majority of protest activity fell within the remit of the right to peaceful assembly, such claims would appear to be legally unfounded, rendering GMP's request unlawful.

\section{Liberty and security of person}

The right to liberty and security of person is articulated in Article 5 of both the HRA ${ }^{232}$ and ECHR, ${ }^{233}$ and Article 9 of the ICCPR. ${ }^{234}$ This right is of relevance to the context of UK anti-fracking protests due to the arrests made by GMP and Sussex Police, which are required by domestic and international legislation to be lawful in order to not violate this particular right. Indeed, Article 5(1)(c) of both the HRA and the ECHR require 'lawful arrest $[\ldots]$ on reasonable suspicion of having committed an offence', and Article 9(1) of the ICCPR states that 'No one shall be subjected to arbitrary arrest or detention.' In addition, Article 5(2) of both the HRA and the ECHR states that 'Everyone who is arrested shall be informed promptly [...] of the reasons for his arrest and of any charge against him', and Article 9(2) of the ICCPR states that '[a]nyone who is arrested shall be informed, at the time of arrest, of the reasons for his arrest and shall be promptly informed of any charges against him'. Any arrest made which could be deemed unlawful under the above descriptions would therefore violate the right of the individual arrested to liberty and security of person.

First, references were made in several interviews to the concept of arrest quotas, whereby police would carry out specific numbers of arrests over consecutive days. At Barton Moss, throughout the autumn and winter of 2013, one interview respondent recalled how 'there were five arrests every day', and that 'officers were heard to say "We need one more arrest.",235 There was a belief that the use of arrest quotas was 'almost certainly 
planned in advance', and designed as 'a long term plan' which would ensure that 'eventually everyone would be arrested' ${ }^{236}$ More explicitly, patterns of arrest seemed to follow this trajectory: 'you're arrested, you get bailed, next time you get arrested in breach of bail'. ${ }^{237}$ Over a period of time, such a cycle would decrease the effectiveness of the protest camp's actions and increase the likelihood of its disbandment.

In addition to arrest quotas, ${ }^{238}$ interview respondents referenced the use of arbitrary arrests in both Balcombe and Barton Moss, whereby individuals felt arrests had no legal basis and were used as a way of 'undermining people's morale' because 'it puts people off protesting'. ${ }^{239}$ Arrests were described variously as 'clearly random', 240 'quite random, ${ }^{241}$ and 'completely random', ${ }^{242}$ with one respondent expressing the most telling sentiment, that: 'there was a risk that at any time you could be arrested'. ${ }^{243}$ Such arrests, made without legal basis, would be in direct contravention of the right to liberty and security of person. The prevalence of violations is best indicated by the discrepancy between the numbers of arrests of anti-fracking protestors in Balcombe, 126 in total, with those who have been found guilty and sentenced in court, a mere $14 .{ }^{244}$ In addition to quotas and arbitrary arrests, allegations were made during an interview of arrests being knowingly made on unlawful charges by GMP. At Barton Moss, the lorries travelled down Barton Moss Lane to reach the IGas drilling site, a designated private road with footpath access for the public, which is, according to an interview respondent who resides in the area, 'clearly signposted at the top'. ${ }^{245}$ The same respondent described how police made arrests on Barton Moss Lane for 'the crime of obstructing a public highway', which is an entirely unlawful charge given that the road is private with public footpath access, and therefore does not constitute a public highway. ${ }^{246}$ Furthermore, the respondent described how, at a court hearing of individuals charged with this crime in November 2013, 'a solicitor informed the court that Barton Moss Lane was a private road which has public footpath access'. ${ }^{247}$ However, the respondent states that GMP 'continued to make arrests under that crime until $[\ldots]$ February', meaning that, 'for nearly three months they continued to arrest for a crime that wasn't a crime'. ${ }^{248}$

Thus in this example, both the initial and later arrests are therefore unlawful, causing violations of the right to liberty and security of person through failing to comply with basic requirements of lawful detention. As an additional requirement of making lawful arrests, police officers must, as indicated above, inform individuals of the charges under which they are being arrested. One interview respondent described how, at Barton Moss ' $[\ldots]$ when people were arrested, if they were told anything, it was when they were separated from the walk $[\ldots]$ once they were actually in the police van they might be told what they were being arrested for'. ${ }^{249}$ Another respondent stated, also with reference to Barton Moss and the GMP, 'the police have been acting illegally at various times and they've been impeding the legal right to protest', with specific reference here to unlawful arrests. ${ }^{250}$ Such testimony suggests that the GMP's actions were designed to disrupt the anti-fracking protestors' right to freedom of peaceful assembly, apparently through unlawful activity.

\section{Fair trial}

The right to a fair trial is articulated in Article 6 of the $\mathrm{HRA}^{251}$ and ECHR ${ }^{252}$ and Article 14 of the ICCPR. ${ }^{253}$ Article 6(3) of the HRA and ECHR detail the 'minimum rights' which an individual charged with a criminal offence is entitled to, and Article (14)(3) of the ICCPR is similarly concerned with such 'minimum guarantees'. Under these provisions an individual must 'be informed promptly [...] and in detail, of the nature and cause of the accusation 
against him'. Consequently, any instance in which an anti-fracking protestor is arrested and not informed 'promptly' of the charges or suspicion under which he or she is being charged, would contravene the right to a fair trial in the HRA, ECHR and ICCPR. As we outlined earlier, such circumstances have been experienced at Barton Moss protests.

The arrest of protestors on Barton Moss Lane for the crime of obstructing a public highway also concerns the right to a fair trial through connections with the provision of legal aid. As discussed above, protestors were unlawfully arrested in 2013 and early 2014 for obstructing a public highway whilst walking in front of lorries on Barton Moss Lane. An interview respondent involved with the Barton Moss protests described how individuals 'can't claim legal aid for an offence of obstruction of a public highway under the current rules', ${ }^{254}$ and expressed concern that GMP's continued arrest of protestors under this crime was a deliberate ploy to ensure protestors 'wouldn't be able to defend themselves' financially. ${ }^{255}$ In legislative terms, Article 6(3)(c) of the HRA and ECHR detail the minimum right that any individual charged with an offence and without financial provision for legal representation 'be given it free when the interests of justice so require', and Article 14(3)(d) of the ICCPR similarly states that any such individual must 'have legal assistance assigned to him, in any case where the interests of justice so require'. By charging protesters with a crime which legal aid was not provided for, GMP and, perhaps more so - the Crown Prosecution Service, were knowingly prompting judicial proceedings in which many protesters would be unable to meet the financial costs of a court case. If protesters had instead been arrested for crimes which did receive legal aid, and indeed were actual crimes in this context, such a tactic would have no basis. Fortunately, pro bono legal support was provided, or protesters would have been prevented from being able to obtain legal representation against the charges they faced. In that scenario, given the unlawful nature of the initial arrest, the 'interests of justice' would have been seriously compromised.

\section{Respect for a private and family life}

The right to a private and family life is articulated in Article 8 of both the HRA ${ }^{256}$ and the ECHR, ${ }^{257}$ as 'Everyone has the right to respect for his private and family life, his home and his correspondence', while Article 17(1) of the ICCPR states that 'No one shall be subjected to arbitrary or unlawful interference with his privacy, family, home or correspondence.' It is the precise wording of these articles which allows for interpretations to be made as to how this right has been threatened or violated in the context of anti-fracking protests, through monitoring of communications and covert surveillance of protestors.

Several interview respondents raised concerns of police surveillance of email accounts, telephones and social media. Although, as one interview respondent indicated, such activities are 'difficult to prove', ${ }^{258}$ other interview respondents were insistent in their belief of surveillance activity, stating that 'We knew that they were monitoring our Facebook pages, our emails and our phones' at both Balcombe and Barton Moss, ${ }^{259}$ and 'I have no doubt that they were bugging certain people's phones' and 'keeping a close eye on people's Facebook pages' in Balcombe. ${ }^{260}$ Concerns for some anti-fracking protestors over the security of information were such that one respondent described how, when important details about protest action in Balcombe required discussion, the individuals involved would 'get together and speak about it rather than using [social] media'. ${ }^{261}$ Seemingly to confirm fears of surveillance, another respondent described how a list of press contacts on an email account were 'scrambled', ${ }^{262}$ preventing messages from reaching the majority of the list. 
In addition to covert surveillance through technology, members of the anti-fracking movement have become increasingly concerned over police infiltration via social media accounts or undercover individuals joining specific campaigns or protest camps. Indeed, a request made as part of this primary research for online survey respondents was met with the suggestion that the collation of such information was likely to be a database for police use. Furthermore, one respondent believed that the police were providing drilling companies with information gathered about protestors, stating that 'We'd have to strongly suspect $[\ldots]$ that covert intelligence was shared between Greater Manchester Police and iGas. ${ }^{263}$ Such mistrust indicates significant concerns surrounding the police, the internet and confidentiality. It also demonstrates why concerned individuals, as mentioned above, prefer face-to-face conversations over online or telephone interactions.

In order for any surveillance of communications to be lawful, Article 8(1) of both the HRA and ECHR require that any restrictions placed upon the right to respect for a private and family life are ' $[\ldots]$ in accordance with the law and [are] necessary in a democratic society in the interests of national security, public safety or the economic well-being of the country, for the prevention of disorder or crime'. The use of covert surveillance by either GMP or Sussex Police would indicate a belief that anti-fracking protesters threatened 'national security' or 'public safety', or increased the possibility of 'disorder or crime'. As mentioned previously with reference to the right to freedom of expression, given that the majority of protest activity fell within the remit of the right to peaceful assembly, such claims would appear to be without legal foundation.

In the UK, potential future rights concerns may well go beyond circumstances surrounding specific protest sites if the behaviour of Kent police towards an open academic debate is indicative of a national policing approach towards this issue. In November 2014 they asked a university to provide a list of members of the public who were due to attend a public debate on fracking. ${ }^{264}$ From subsequent 'freedom of information' requests it was revealed that if such a list were forthcoming Kent police would have conducted 'some R\&D'265 - presumably meaning the individuals would be researched somehow. Such police behaviour should not be analysed as if it occurs in a vacuum. It is vital to consider the broader political context and in particular the "political spectacle"266 that has been constructed around fracking in the UK. On the surface it may seem that the extraction of shale gas is considered necessary for 'the economic well-being of the UK' and hence 'in the national interest', and is simply being prioritised over individuals' fundamental civil and political rights; but if we were to investigate a little deeper, a more politically concerning picture may emerge, especially considering recent evidence likening the precarious nature of the US 'fracking boom ${ }^{267}$ to that of a government supported 'Ponzi scheme'. ${ }^{268}$

As Noam Chomsky warns, 'the terms, United States, Australia, Britain, and so on, are now conventionally used to refer to the structures of power within such countries: the "national interest" is the interest of these groups, which correlates only weakly with the interests of the general population'. ${ }^{269}$ A critical awareness of such observations is vital to conducting nuanced interdisciplinary HRIAs in our view. Such assessments should, as far as possible, investigate and analyse the 'close relationship between governments and powerful multinational corporations', which de Rijke ${ }^{270}$ warned of with unconventional gas production in the Australia, and its impact on policy and the subsequent policing of dissenting voices. For example, in the UK much of the public fracking debate has been conducted in a context which involves a government wanting to 'go all out for shale' while at the same time having a 'lead non-executive director' at the Cabinet Office, Lord Browne, who is also the Chairman of shale gas company Cuadrilla Resources. There have been illuminating 'freedom of information' requests in the UK that have demonstrated collusion 
between key politicians and industry figures on such matters as how best to 'manage' public perceptions and manufacture consent in order to 'fast track' fracking development. ${ }^{271}$ Environmental consultant and extreme energy expert Paul Mobbs has highlighted numerous political-industry connections that are deserving of public attention and which raise fears of 'malfeasance' in public office. ${ }^{272}$ Mobbs argues, 'politicians might call for a "balanced debate on shale", but arguably it is they who are peddling a manufactured rhetoric. ${ }^{273}$ This is because the political process has been hijacked by lobbyists paid by the industry, whose manipulative tendrils reach right inside the Government. ${ }^{274}$

By drawing upon the experience of individuals in the UK, this discussion has sought to expose the extent to which the civil and political rights of anti-fracking protestors and individuals living in proximity to exploratory drilling sites have been threatened or violated as a result of the proposed introduction of fracking. The police response to anti-fracking protests, seemingly prompted by the need to protect governmental policy, has violated the right to freedom of peaceful assembly itself, in addition to threatening and violating other rights in the context of anti-fracking protests. Arguably then, the proposal of introducing fracking in the UK has already violated internationally and domestically recognised rights, with actual implementation of this particular method of energy extraction expected to only further impact human rights, of an economic, social and cultural nature as well as civil and political.

\section{Anthropogenic climate change}

While issues such as industrialisation of the landscape, water, air, noise pollution and citizens' ability to participate and protest are all important issues to consider in human rights impact assessments, perhaps the most important issue to consider is fracking's impact on greenhouse gas emissions and anthropogenic climate change. The latest climate science suggests that we can only burn approximately one-third ${ }^{275}$ of known conventional fossil fuel reserves if we are to avoid catastrophic, runaway climate change. ${ }^{276}$ Thus, scientists such as James Hansen and Kevin Anderson argue that unconventional sources such as shale gas need to be left in the ground. Indeed, taking recent climate science seriously calls into question the whole idea of 'unconventional' extraction. If we are to avoid runaway climate change and a potential extinction event for mankind, then, as leading climate scientist James Hansen puts it, 'we must rapidly phase out coal emissions, leave unconventional fossil fuels in the ground, and not go after the last drops of oil and gas. In other words, we must move as quickly as possible to the postfossil fuel era of clean energies. ${ }^{277}$ Tyndall Centre climate scientist Kevin Anderson concurs, 'the only responsible action with regard to shale gas, or any 'new' unconventional fossil fuel, is to keep it in the ground - at least until there is a meaningful global emissions cap forcing substitution. In the absence of such an emissions cap, and in our energy hungry world, shale gas will only be combusted in addition to coal - not as a substitution, as many analysts have naively suggested. ${ }^{278}$ Despite this, there is considerable industry and government propaganda concerning the use of unconventional gas as a so-called 'bridge fuel', a proposition which is highly dubious and likely false. Robert Howarth's recent paper 'A Bridge to Nowhere: Methane Emissions and the Greenhouse Gas Footprint of Natural Gas' shows that over the crucial 20-year-period (in which we need to drastically reduce emissions to avoid the worst of climate change), both shale gas and conventional natural gas have a larger GHG footprint than do coal or oil, largely due to fugitive methane emissions. 
While no explicit legal right to protection from climate change - or similar - exists, the negative effect of climate change on the enjoyment of numerous human rights is well documented. A connection between climate change and human rights was first drawn by the Inuit Circumpolar Council in their 2005 petition to the Inter-American Commission of Human Rights Case against the US. ${ }^{279}$ The Inuit Council claimed that excessive greenhouse gas emissions from the US violated their right to culture through advancing climate change. While this case was dismissed by the Inter-American Commission as inadmissible, ${ }^{280}$ it brought considerable attention to two important texts: the International Council on Human Rights Policy report which highlighted the 'human rights concerns raised by anthropogenic climate changes ${ }^{281}$ and Human Rights Council Resolution 7/23 which explicitly states ' ... climate change poses an immediate and far-reaching threat to people and communities around the world and has implications for the full enjoyment of human rights'. ${ }^{282}$ An Office of the High Commissioner for Human Rights (OHCHR) study on climate change, called for in Resolution 7/23, was conducted later that same year and not only elaborated on human rights violations due to climate change, but also upon the legal mechanisms in human rights, environmental and other areas of law that oblige states to address climate change and protect their denizens from its consequences. ${ }^{283}$ Following the study, in 2009 Human Rights Council Resolution 10/4 stated that climate change is currently directly and indirectly negatively affecting human rights, ${ }^{284}$ a view that was affirmed by the Human Rights Council Panel Discussion on the relationship between climate change and human rights later that year. ${ }^{285} \mathrm{~A}$ seminar convened by the OHCHR in 2012 also found the same conclusion. ${ }^{286}$ Indeed, from the above discussions of various human rights and their relationship to the environment, as well as the consequences of climate change, the threat of climate change to the minimally good life is immediately apparent, and, therefore, the right to live free from the negative effects of climate change should be considered implicit within the human rights legal framework. Thus, via its contribution to anthropogenic climate change we find another possible avenue through which fracking activities are capable of violating human rights.

\section{Conclusion}

The hegemonic neoliberal version of capitalism under which most of us now live has such a significant thirst for fossil fuels that their extraction tends to trump all other concerns. As resources become scarcer and we scrape the bottom of the fossil fuel barrel through the use of more energy intensive, higher risk and environmentally destructive extraction processes, the relationship between resource development and human rights becomes ever more problematic. Indeed, human rights violations due to climate change are but another side effect of humanity's dependence on fossil fuels that is growing in magnitude with each passing decade. These violations are likely to increase and be felt more acutely as resources are depleted, quite possibly until the sharp population decline predicted in The Limits to Growth occurs. If there were not considerable evidence emerging, on an almost daily basis, concerning the actual, and potential, impacts and dangers of fracking development in countries with a mature industry such as the US, Canada and Australia, ${ }^{287}$ it is highly likely that the UK's anti-fracking movement would not be its fastest growing social movement and the protests in which violations of civil and political rights have occurred may not have taken place. As things stand, however, it seems that citizens' civil and political rights are being violated in defence of their environmental, economic, social and cultural rights.

This article has shown the extent to which the process and infrastructure of fracking developments has the capacity to threaten and violate a wide range of internationally 
recognised human rights, including rights to water, air, land and health. Additionally, our research suggests the rights to peaceful assembly, freedom of expression, liberty and security of the person, fair trial and a private and family life have also been violated in the state response to protests opposing fracking development. These rights encompass the principles codified in international human rights legislation and the civil liberties recognised in many state constitutions. It is only with more research into the actual impact of these energy technologies on human rights that violations can be identified and hopefully stopped and remedied. Importantly this research must be industry independent, and must do more than appear on annual CSR statements. It should also be independent of government given the close relationships between governments and extractive industries and the tendency of government-sponsored reports to be suspiciously limited ${ }^{288}$ or to include dubious 'REDACTED' sections on public release. ${ }^{289}$ In sum, there is an urgent need for independent, comprehensive, evidence-based interdisciplinary HRIAs to provide valuable impact data and analysis. Such assessments will be a vital tool for communities in the defence of their rights when faced with immanent extreme energy developments and governments intent on unsustainable fossil fuel extraction.

\section{Notes on contributors}

Damien Short is Reader in Human Rights and Director of the Human Rights Consortium and the Extreme Energy Initiative (http://extremeenergy.org) at the School of Advanced Study, University of London. He has published extensively on indigenous peoples' rights, reconciliation projects, colonialism and genocide studies. His more recent work concerns the genocide ecocide nexus and the role of extreme energy. He can be contacted on Damien.short@sas.ac.uk.

Kadin Norder is a Research Associate at the Human Rights Consortium with interests in the connections between human rights, economics, governance, and the environment. She previously conducted research for the Commonwealth Human Rights Initiative and the U.S. White House. She works for the Rights of Nature European Citizen's Initiative in Sweden.

Jess Elliot is a Research Associate of the Human Rights Consortium, and has co-authored articles with Damien Short for The Ecologist and The Conversation on the impact of fracking on civil and political rights. Her research interests lie primarily with the impact of extractive industries upon human rights and the environment. Jess currently works as part of the British Red Cross Refugee Support team.

Ed Lloyd-Davies is a Research Associate of the Human Rights Consortium. He trained as an astrophysicist at the University of Birmingham and has worked for over 10 years as a postdoctoral fellow at the University of Michigan and the University of Sussex. He has been involved in writing over 20 papers on extragalactic astrophysics and cosmology. He now works as a freelance researcher, focusing on environmental issues, particularly extreme energy.

Joanna Morley is a Research Associate at the Human Rights Consortium with interests in the connections between human rights, development, business and international governance. She is currently completing an MA in Understanding and Securing Human Rights at the Institute of Commonwealth Studies in London, England.

\section{Disclosure statement}

No potential conflict of interest was reported by the authors.

\section{Notes}

1. Olivia Ball and Paul Gready, No-nonsense Guide to Human Rights (Oxford: New Internationalist, 2006); Upendra Baxi, The Future of Human Rights (New Delhi: Oxford University Press, 2002); Rhonda L. Callaway and Julie Harrelson-Stephens, eds, Exploring International Human 
Rights: Essential Readings (London: Lynne Reiner, 2007); Marie-Bénédicte Dembour and Richard Wilson, eds, Culture and Rights: An Anthropological Perspective (Cambridge: Cambridge University Press, 2001), 1-26; Jack Donnelly, Universal Human Rights in Theory and Practice (Ithaca, NY: Cornell University Press, 2003); Michael Freeman, Human Rights: An Interdisciplinary Approach (Cambridge: Polity, 2002); Michael Goodhart, ed., Human Rights Politics and Practice (Oxford: Oxford University Press, 2010); Gerd Oberleitner, Global Human Rights Institutions (Cambridge: Polity, 2007); Rhona Smith and Christien van den Anker, The Essentials of Human Rights (London: Hodder Arnold, 2005).

2. 'Minimalist' in the sense that Nickel argues, correctly in our view, that human rights are not ideals of the good life for humans, they are rather concerned with ensuring conditions, negative and positive, of a 'minimally good life'.

3. James Nickel, Making Sense of Human Rights, 2nd ed. (Oxford: Blackwell, 2007), 138.

4. Ibid.

5. Martin Crook and Damien Short, 'Marx, Lemkin and the Genocide-Ecocide Nexus', International Journal of Human Rights 18, no. 3 (2014): 298-319 (Special Issue: Climate Change, Environmental Violence and Genocide, ed. Jurgen Zimmerer).

6. Rhoda Howard-Hassmann, 'The Second Great Transformation: Human Rights Leapfrogging in the Era of Globalization', Human Rights Quarterly 27, no. 1 (2005): 1-40; Adamantia Pollis, 'Commentary on the Second Great Transformation', Human Rights Quarterly 27, no. 3 (2005): 1120-1; Rhoda Howard-Hassmann, 'Reply to Adamantia Pollis', Human Rights Quarterly 28, no. 1 (2006): 277-8.

7. Donella H. Meadows et al., The Limits to Growth: A Report for the Club of Rome's Project on the Predicament of Mankind (New York: Universe Books, 1972).

8. Graham Turner, A Comparison of the Limits to Growth with 30 Years of Reality, Socio-Economics and the Environment in Discussion CSIRO Working Paper Series 2008-09 (Canberra: CSIRO Sustainable Ecosystems, 2007).

9. As oil and natural gas production peaks and declines, coal becomes increasingly pivotal in maintaining global energy consumption rates; however, this renewed focus on coal, seen in the 'record rate' of coal gasification and coal-to-liquid plant construction of the last decade, will only further exacerbate strained coal resources. Indeed, world coal production continues to increase annually, with an overall increase of over $67 \%$ between 1990 and 2013 . Even with more conservative estimates of coal production growth and the most opportunistic estimates of global coal reserves - relying on the World Coal Association's production growth rate of $0.4 \%$ between 2012 and 2013 remaining constant and the German Federal Institute for Geosciences and Natural Resources' estimate of 1052 billion tonnes of reserves - the world will 'run out' of coal in just over a century. As that figure assumes no 'updates' to reserve figures (despite nearly every state with 'significant coal resources' reporting a 'substantial downward revision' in reserve estimates made since 1986) or increase in production rate (despite the sharp decreases in available oil and natural gas during the upcoming decades), it is reasonable to conclude that the limits to coal-dependent growth will also soon be reached. Richard Heinberg, 'Peak Coal: Sooner Than You Think', On Line Opinion, 21 May 2007, http://www.onlineopinion.com.au/ view.asp?article=5869; World Coal Association, 'Coal Statistics', http://www.worldcoal.org/ resources/coal-statistics.

10. Richard Heinberg, Snake Oil: How Fracking's False Promises of Plenty Imperils Our Future (West Sussex: Clairview Books, 2014).

11. James Murray and Jim Hansen, 'Peak Oil and Energy Independence: Myths and Reality', Eos 94, no. 28 (2013): 245-52.

12. Natural gas liquids (NGLs) are 'hydrocarbons with longer molecular chains', such as propane and butane, within natural gas that are captured and used for heating and industrial purposes. Heinburg, Snake Oil, 25.

13. Paul Mobbs, 'Sheet E1. Peak Energy: The Limits to Oil and Gas Production', Free Range 'Energy Beyond Oil' Project, http://www.fraw.org.uk/publications/e-series/e01/e01-peak_ energy.html; Heinberg, Snake Oil, 25.

14. Conventional natural gas production follows a similar peak and decline bell-curve and is expected to reach its plateau before the mid-twenty-first century. See: Mobbs, 'Sheet E1'; Gaetano Maggio and Gaetano Cacciola, 'When Will Oil, Natural Gas, and Coal Peak?', Fuel 98 (2012): 111-23. 
15. We have in mind here both the Gulf War of 1990/1991 and the Iraq War of 2003-2011, though the UN Security Council sanctions against Iraq in the interim also indicate the willingness of Western states to take international action to gain control of oil exports when their native government is considered unreliable.

16. Jon Barnett, 'Environmental Security and U.S. Foreign Policy', in The Environment, International Relations, and U.S. Foreign Policy, ed. P. G. Harris (Washington, DC: Georgetown University Press, 2001), 68-91.

17. See: US National Security Strategy, A National Security Strategy for a New Century (Washington, DC: The White House, 1998).

18. Exxon's revenue is greater than the gross domestic product of Thailand, for instance. Vincent Trivett, '25 US Mega Corporations: Where They Rank If They Were Countries', Business Insider, 27 June 2011, http://www.businessinsider.com/25-corporations-bigger-tan-countries2011-6?op=1.

19. Jane Mayer, 'Covert Operations: The Billionaire Brothers Who Are Waging a War Against Obama', The New Yorker, 30 August 2010, http://www.newyorker.com/magazine/2010/08/ 30/covert-operations.

20. Fred Bedell, 'Economic Injustice as an Understanding of the Existence of Two Americas Wealth and Poverty', Open Journal of Political Science 4, no. 3 (2014): 101-8.

21. Paul Mobbs, "Economically and Politically Fracked: "Behind Every Picture Lies a Story" Statistical Reality versus PR-Hype within the Political Project of Unconventional Gas in Britain', Mobbsey's Musings, 25 July 2013, http:/www.fraw.org.uk/mei/musings/2013/ 20130725-behind_every_picture_lies_a_story.html.

22. See the excellent work of investigative journalist Greg Palast on this point - Greg Palast, The Best Democracy Money Can Buy: An Investigative Reporter Exposes the Truth About Globalization, Corporate Cons and High Finance Fraudsters (Pluto Press: London, 2002).

23. United States Congress, Energy Policy Act, Pub.L. 109-58 (2005).

24. BBC, 'Lords: Fracking Should Be "Urgent Priority" for UK', BBC News: Business, 8 May 2014, http://www.bbc.co.uk/news/business-27312796.

25. Damian Carrington, 'UK Defeats European Bid for Fracking Regulations', The Guardian, 14 January 2014, http://www.theguardian.com/environment/2014/jan/14/uk-defeats-europeanbid-fracking-regulations.

26. Michael J. Lynch, Ronald G. Burns, and Paul B. Stretesky, 'Global Warming and State-Corporate Crime: The Politicalization of Global Warming under the Bush Administration', Crime, Law and Social Change 54, nos 3-4 (2010): 213-39.

27. The Economist, 'Energy Firms and Climate Change: Unburnable Fuel', The Economist, 4 May 2013, http://www.economist.com/news/business/21577097-either-governments-are-notserious-about-climate-change-or-fossil-fuel-firms-are.

28. For more on corporate-state connections, see: Noam Chomsky, 'Can Civilization Survive Capitalism?', AlterNet, 5 March 2013, http://www.alternet.org/noam-chomsky-can-civilizationsurvive-capitalism; Palast, The Best Democracy Money Can Buy.

29. For example, the American Enterprise Institute, which receives funding from ExxonMobil and other companies in the energy sector, 'offered a $\$ 10,000$ incentive to scientists and economists to write papers challenging the IPCC findings' after the Intergovernmental Panel on Climate Change released its fourth assessment report in 2007. Charles A. Jones and David L. Levy, 'Business Strategies and Climate Change', in Changing Climates in North American Politics, ed. H. Selin and S.D. VanDeveer (Cambridge: MIT Press, 2009), 219-240.

30. IPCC, 'Summary for Policymakers', in Climate Change 2013: The Physical Science Basis. Contribution of Working Group I to the Fifth Assessment Report of the Intergovernmental Panel on Climate Change, ed. T.F. Stocker et al. (Cambridge: Cambridge University Press, 2013), 3-29.

31. Bärbel Hönisch et al., 'The Geological Record of Ocean Acidification Science', Science 335, no. 6072 (2012): 1058-63.

32. IPCC, Climate Change 2013: The Physical Science Basis. Contribution of Working Group I to the Fifth Assessment Report of the Intergovernmental Panel on Climate Change (Cambridge: Cambridge University Press, 2013).

33. IPCC, 'Summary for Policymakers'.

34. Office of the Chief Economist, World Energy Outlook: 2011 (Paris: International Energy Agency, 2011). 
35. Joel Bakan, The Corporation: The Pathological Pursuit of Profit and Power (London: Constable and Robinson, 2005).

36. Robert C. Hinkley, 'How Corporate Law Inhibits Social Responsibility', Humanist 62, no. 2 (2002): 26. Also: Bakan, The Corporation. For further reading on the economic model and psychology under which corporations operate, see: Diane Elson, 'Human Rights and Corporate Profits: The UN Global Compact - Part of the Solution or Part of the Problem?', in Global Tensions: Challenges and Opportunities in the Global Economy, ed. L. Bernia and S. Bisnath (London: Routledge, 2002); and Nicholas Connolly, 'Corporate Social Responsibility: A Duplicitous Distraction?', International Journal of Human Rights 16, no. 8 (2012): 122849. Notably, even privately held companies, such as Koch Industries, have a monetary interest in maintaining global fossil fuel use, as long as non-renewable energy sources continue to generate profit.

37. US Energy Information Administration, 'Renewable \& Alternative Fuels', http://www.eia. gov/renewable/.

38. For example, in 2009 approximately $\$ 43-46$ billion was provided to renewable and biofuel technologies, projects and companies by the governments of the world, compared with the $\$ 577$ billion spent on fossil fuel subsidies in 2008. Bloomberg: New Energy Finance, 'Subsidies for Renewables, Biofuels Dwarfed by Supports for Fossil Fuels', http://about.bnef.com/ press-releases/subsidies-for-renewables-biofuels-dwarfed-by-supports-for-fossil-fuels/.

39. This concept is perhaps best illustrated by the insistence from both industry and governments that hydraulic fracturing will allow natural gas to replace the use of coal and thus reduce the emission of greenhouse gases, when in actuality the abundance of hydraulic fracturing in the US has simply lowered the price of US coal and driven up exports. Damian Carrington, 'Fracking Boom Will Not Tackle Global Warming, Analysis Warns', The Guardian, 15 October 2014, http://www.theguardian.com/environment/2014/oct/15/gas-boom-from-unrestrainedfracking-linked-to-emissions-rise; Thoman K. Grose, 'As U.S. Cleans Its Energy Mix, It Ships Coal Problems Abroad', National Geographic: News, 15 March 2013, http://news. nationalgeographic.com/news/energy/2013/03/130315-us-coal-exports/.

40. Ibid.

41. UNEP, 'Athabasca Oil Sands, Require Massive Investments and Energy and Produce Massive Amounts of Oil and CO2 - Alberta (Canada)', United Nations Environment Programme 54, Global Environment Alert Service (2011): 1-5; UNEP, 'Oil Palm Plantations: Threats and Opportunities for Tropical Ecosystems', United Nations Environment Programme 73, Global Environment Alert Service (2011): 1-10.

42. Michael Klare, 'The Era of Extreme Energy: Life after the Age of Oil', The Huffington Post, 25 May 2011, http://www.huffingtonpost.com/michael-t-klare/the-era-of-xtreme-energy_b_ 295304.html.

43. Edward Lloyd-Davies, 'Defining Extreme Energy: A Process not a Category', Extreme Energy Initiative: Working Paper Series, 25 July 2013, http://extremeenergy.org/2013/07/25/definingextreme-energy-a-process-not-a-category/.

44. Euran Mearns, 'The Global Energy Crises and its Role in the Pending Collapse of the Global Economy' (Paper presented at the Royal Society of Chemists, Aberdeen, Scotland, 29 October 2008).

45. At the time of writing oil prices were in decline but the finite nature of the resource guarantees that prices will again rise.

46. David J. Murphy, 'EROI, Insidious Feedbacks, and the End of Economic Growth' (Paper presented at the Sixth Annual Conference of the Association for the Study of Peak Oil (ASPO), Washington, DC, 7-9 October 2010).

47. On this point see also Heinberg, Snake Oil.

48. Stephen J. Purdey, Economic Growth, the Environment and International Relations: The Growth Paradigm (Oxon: Routledge, 2010).

49. International Energy Agency, Key World Energy Statistics (Paris: International Energy Agency, 2013).

50. Lloyd-Davies, 'Defining Extreme Energy'.

51. Notwithstanding the current, inevitably temporary, geo-politically induced price reduction, prices will undoubtedly rise over time as supply declines, see Mobbs, P. 'Environmentalists' Oil Price Panic Reflects their Own Existential Crisis', The Ecologist, 8 January 2015, 
http://www.theecologist.org/blogs_and_comments/commentators/2703420/environmentalists_ oil_price_panic_reflects_their_own_existential_crisis.html.

52. Heinberg, Snake Oil.

53. Stephanie Malin, 'There's No Real Choice but to Sign: Neoliberalization and Normalization of Hydraulic Fracturing on Pennsylvania Farmland', Journal of Environmental Studies and Sciences 2014, no. 4 (2013): 17-27.

54. Lloyd-Davies, 'Defining Extreme Energy'. See also: Jennifer Huseman and Damien Short, 'A Slow Industrial Genocide: Tar Sands and the Indigenous Peoples of Northern Alberta', The International Journal of Human Rights 16, no. 1 (2012): 216-37; Stephen Humphreys, Climate Change and Human Rights: A Rough Guide (Geneva: International Council on Human Rights Policy, 2008).

55. IPCC, 'Summary for Policymakers', in Climate Change 2007: The Physical Science Basis. Contribution of Working Group I to the Fourth Assessment Report of the Intergovernmental Panel on Climate Change, ed. S. Solomon et al. (Cambridge: Cambridge University Press, 2007), 1-18.

56. Jonathan Patz et al., 'Impact of Regional Climate Change on Human Health', Nature 438 (2005): 310-17.

57. Laboratory for Aviation and the Environment, 'Air Pollution Causes 200,000 Early Deaths Each Year in the U.S.', Massachusetts Institute of Technology, http://lae.mit.edu/?p=2821.

58. Peter Stott, Dáithí Stone, and Myles Allen, 'Human Contribution to the European Heatwave of 2003', Nature 432 (2004): 610-14.

59. Alok Jha, 'Boiled Alive', The Guardian, 26 July 2006, http://www.theguardian.com/ environment/2006/jul/26/science.g2.

60. Meadows et al., The Limits to Growth.

61. IPCC, 'Projections of Future Changes in Climate', in Climate Change 2007: The Physical Science Basis. Contribution of Working Group I to the Fourth Assessment Report of the Intergovernmental Panel on Climate Change, ed. S. Solomon et al. (Cambridge: Cambridge University Press, 2007), 12-18.

62. World Health Organisation (WHO) Regional Office for Europe, Euroheat: Improving Public Health Responses to Extreme Weather Heat-Waves. Summary for Policy-Makers (Copenhagen: World Health Organization, 2009).

63. IPCC, 'Projections of Future Changes in Climate'.

64. IPCC, Climate Change 2014: Impacts, Adaptation, and Vulnerability. Part A: Global and Sectoral Aspects. Contribution of Working Group II to the Fifth Assessment Report of the Intergovernmental Panel on Climate Change (Cambridge: Cambridge University Press, 2014).

65. See: John Barry and Kerri Woods, 'The Environment', in Human Rights: Politics and Practice, ed. M. Goodhart (Oxford: Oxford University Press, 2010), 380-395; Nafeez Ahmed, 'Are You Opposed to Fracking? Then You Might Just Be a Terrorist', The Guardian, 21 January 2014, http://www.theguardian.com/environment/earth-insight/2014/jan/21/ fracking-activism-protest-terrorist-oil-corporate-spies; Human Rights Council, 'Report of the Special Rapporteur on the Human Right to safe Drinking Water and Sanitation: Mission to the United States of America', A/HRC/18/33/Add.4, (2011): 10-11.

66. See Huseman and Short, 'A Slow Industrial Genocide'.

67. S. Perry, 'Development, Land Use, and Collective Trauma: The Marcellus Shale Gas Boom in Rural Pennsylvania', Culture, Agriculture, Food and Environment 34, no. 1 (2012): 81-92, 81.

68. See Heinberg, Snake Oil.

69. Reports of considerable negative impacts go well beyond the anecdotal realm, see for example environmental and health studies such as V.J. Brown, 'Radionuclides in Fracking Wastewater: Managing a Toxic Blend', Environmental Health Perspectives 122, no. 2 (2014): A50A55; R. McDermott-Levy, N. Kaktins, and B. Sattler, 'Fracking, the Environment, and Health: New Energy Practices May Threaten Public Health', American Journal of Nursing 113, no. 6 (2013): 45-51; C.W. Moore, B. Zielinska, G. Petron, and R.B. Jackson, 'Air Impacts of Increased Natural Gas Acquisition, Processing, and Use: A Critical Review', Environmental Science and Technology (2014), dx.doi.org/10.1021/es4053472; S. Osborn, A. Vengosh, N.R. Warner, and R.B. Jackson, 'Methane Contamination of Drinking Water Accompanying Gas-well Drilling and Hydraulic Fracturing', Proceedings of the National Academy of Sciences of the United States of America 108, no. 20 (2011), http://www.pnas. org/cgi/doi/10.1073/pnas.1100682108; and A. Vengosh, R.B. Jackson, N. Warner, T.H. Darrah, and A. Kondash, 'A Critical Review of the Risks to Water Resources from 
Unconventional Shale Gas Development and Hydraulic Fracturing in the United States', Environmental Science and Technology (2014), dx.doi.org/10.1021/es405118y; and social scientific enquiries such as Perry, 'Development, Land Use, and Collective Trauma'; B.J. Anderson and G.L. Theodori, 'Local Leaders' Perceptions of Energy Development in the Barnett Shale', Southern Rural Sociology 24, no. 1 (2009): 113-29; B.E. Apple, 'Mapping Fracking: An Analysis of Law, Power, and Regional Distribution in the United States', Harvard Environmental Law Review 38 (2014): 217-44; D. Beach, 'How the Fracking Boom Impacts Rural Ohio', EcoWatch: Transforming Green, 16 September 2013, http:// ecowatch.com/2013/09/16/fracking-boom-impacting-rural-ohio/; R. Gramling and W. Freudenburg, 'Opportunity-Threat, Development, and Adaptation: Toward a Comprehensive Framework for Social Impact Assessment', Rural Sociology 57, no. 2 (1992): 216-34; D.A. Fleming and T.G. Measham, 'Local Economic Impacts of an Unconventional Energy Boom: The Coal Seam Gas Industry in Australia', Australian Journal of Agricultural and Resource Economics (2014), doi:10.1111/1467-8489.12043.

70. Environment and Human Rights Advisory, A Human Rights Assessment of Hydraulic Fracturing for Natural Gas (Oregon: EHRA, 2011), http://www.earthworksaction.org/files/ publications/EHRA_Human-rights-fracking-FINAL.pdf.

71. See: Damien Short, $\bar{K}$ aren Hulme, and Steffen Bohm, 'Don't Let Human Rights Fall to Wayside in Fracking Debate', The Conversation, 24 March 2014, http://theconversation.com/dont-lethuman-rights-fall-to-wayside-in-fracking-debate-24652; Jess Elliot and Damien Short, 'Fracking is Driving UK Civil and Political Rights Violations', The Ecologist (2014); Anna Grear 'Fracking - Human Rights Must Not be Ignored!' The Ecologist, 30 October 2014; Anna Grear, Tom Kerns, Evadne Grant, Karen Morrow, and Damien Short, 'A Human Rights Assessment of Hydraulic Fracturing and Other Unconventional Gas Development in the United Kingdom', Extreme Energy Initiative Report Commissioned by The Bianca Jagger Human Rights Foundation, http://www.sas.ac.uk/sites/default/files/files/UK\%20HRIA $\% 20$ w\%20appdx-hi\%20res.pdf.

72. UNEP, 'Gas Fracking: Can We Safely Squeeze the Rocks?', United Nations Environment Programme, Global Environment Alert Service (2012).

73. Ibid., 6-7.

74. Ibid., 7-9, 12.

75. Robert Howarth, Renee Santoro, and Anthony Ingraffea, 'Methane and the Greenhouse-gas Footprint of Natural Gas from Shale Formations', Climatic Change 106, no. 4 (2011): 679-90; Robert Howarth et al., Methane Emissions from Natural Gas Systems: Background Paper for the National Climate Assessment (2012), http://www.eeb.cornell.edu/howarth/ publications/Howarth_et_al_2012_National_Climate_Assessment.pdf; Robert A. Howarth, 'A Bridge to Nowhere: Methane Emissions and the Greenhouse Gas Footprint of Natural Gas', Energy Science and Engineering 2, no. 2 (2014): 47-60.

76. Stephen Osborn, Avner Vengosh, Nathaniel R. Warner, Robert B. Jackson, 'Methane Contamination of Drinking Water Accompanying Gas-well Drilling and Hydraulic Fracturing', Proceedings of the National Academy of Sciences of the United States of America 108, no. 20 (2011): 8172-6. See also: Isaac Santos and Damien Maher, Fugitive Emissions from Coal Seam Gas, Centre for Coastal Biogeochemistry Research Submission to Department of Climate Change and Energy Efficiency (2012), http://www.scu.edu.au/coastalbiogeochemistry/index.php/70/.

77. Walter Brasch, Fracking Pennsylvania: Flirting with Disaster (Sacramento, CA: Greeley and Stone, 2012).

78. Environment and Human Rights Advisory, 'A Human Rights Assessment'.

79. For example, Gasland, directed by Josh Fox (New York: HBO Productions, 2012); Drill Baby Drill, directed by Lech Kowalski (France: Kowalski Productions, 2013).

80. Kim de Rijke, 'Hydraulically Fractured: Unconventional Gas and Anthropology', Anthropology Today 29, no. 2 (2013): 13-17; Kim de Rijke, 'Coal Seam Gas and Social Impact Assessment: An Anthropological Contribution to Current Debates and Practices', Journal of Economic and Social Policy 15, no. 3 (2013): 3; Kim de Rijke, 'The Agri-Gas Fields of Australia: Black Soil, Food, and Unconventional Gas', Culture, Agriculture, Food and Environment 35, no. 1 (2013): 41-53.

81. Anderson and Theodori, 'Local Leaders' Perceptions of Energy Development in the Barnett Shale'; Kai Schafft, Yetkin Borlu, and Leland Glenna, 'The Relationship between Marcellus 
Shale Gas Development in Pennsylvania and Local Perceptions of Risk and Opportunity', Rural Sociology 78, no. 2 (2013): 143-66; Kai A. Schafft, Leland L. Glenna, Brandn Green, and Yetkin Borlu, 'Local Impacts of Unconventional Gas Development within Pennsylvania's Marcellus Shale Region: Gauging Boomtown Development through the Perspectives of Educational Administrators', Society \& Natural Resources: An International Journal 27, no. 4 (2014): 389-404.

82. Matthew Cotton, Imogen Rattle, and James Van Alstine, 'Shale Gas Policy in the United Kingdom: An Argumentative Discourse Analysis', Energy Policy 73 (2014): 427-38.

83. Malin, 'There's No Real Choice but to Sign'.

84. Paul B. Stretesky, Michael A. Long, and Michael J. Lynch, 'Does Environmental Enforcement Slow the Treadmill of Production? The Relationship between Large Monetary Penalties, Ecological Disorganization and Toxic Releases within Offending Corporations', Journal of Crime and Justice 36, no. 2: (2013): 233-47.

85. Tara Shelley and Tara Opsal, 'Energy Crime, Harm, and Problematic State Response in Colorado: A Case of the Fox Guarding the Hen House?', Critical Criminology 22, no. 4 (2014): 561-77.

86. de Rijke, 'Hydraulically Fractured'.

87. Ibid., 17.

88. S. Bakker, M. Van Den Berg, D. Düzenli, and M. Radstaake, 'Human Rights Impact Assessment in Practice: The Case of the Health Rights of Women Assessment Instrument (HeRWAI)', Journal of Human Rights Practice 1, no. 3 (2009): 436-58; G. De Beco, 'Human Rights Impact Assessments', Netherlands Quarterly of Human Rights 27, no. 2 (2009): 139-66. J. Harrison, 'Human Rights Measurement: Reflections on the Current Practice and Future Potential of Human Rights Impact Assessment', Journal of Human Rights Practice 3, no. 2 (2011): 162-87; P. Hunt and G. MacNaughton, 'Impact Assessments, Poverty, and Human Rights: A Case Study Using the Right to the Highest Attainable Standard of Health', Submitted to UNESCO (2006), http://www.who.int $/ \mathrm{hhr} /$ Series_6_Impact\% 20Assessments_Hunt_MacNaughton1.pdf; G. MacNaughton and P. Hunt, 'A 'A Human Rights-based Approach to Social Impact Assessment', in New Directions In Social Impact Assessment: Conceptual and Methodological Advances, ed. F. Vanclay and A.M. Esteves (Cheltenham, UK: Edward Elgar Publishing, 2011), 355-69.

89. John Ruggie, 'Guiding Principles on Business and Human Rights: Implementing the United Nations "Protect, Respect and Remedy Framework" (2011), http://www.ohchr.org/ Documents/Publications/GuidingPrinciplesBusinessHR_EN.pdf.

90. Simon Walker, The Future of Human Rights Impact Assessments of Trade Agreements (Brussels: Intersentia, 2009), 43; and Simon Walker, 'The United States-Dominican Republic-Central American Free Trade Agreement and Access to Medicines in Costa Rica: A Human Rights Impact Assessment', Journal of Human Rights Practice 3, no. 2 (2011): $188-213$.

91. Harrison, 'Human Rights Measurement', 167; G. De Beco, 'Human Rights Impact Assessments', Netherlands Quarterly of Human Rights 27, no. 2 (2009): 139-66, 147.

92. MacNaughton and Hunt, 'A Human Rights-based Approach to Social Impact Assessment', 361.

93. Ibid., 355 .

94. Anderson and Theodori, 'Local Leaders' Perceptions of Energy Development in the Barnett Shale.

95. Average figures obtained from the US-based www.fracfocus.org website. FracFocus is the national hydraulic fracturing chemical registry. FracFocus is managed by the Ground Water Protection Council and Interstate Oil and Gas Compact Commission, two organisations whose missions both revolve around conservation and environmental protection. FracFocus, 'FracFocus 2.0: Hundreds of Companies. Thousands of Wells', FracFocus, http://www. fracfocus.org.

96. Melissa Stark et al., 'Water and Shale Gas Development: Leveraging the US Experience in New Shale Developments', Accenture (December 2012).

97. Queensland Water Commission, Underground Water Impact Report for the Surat Cumulative Management Area (Queensland: Queensland Water Commission, 2012), http://www.dnrm. qld.gov.au/_data/assets/pdf_file/0016/31327/underground-water-impact-report.pdf. 
98. See for example: Sandra Postel, 'As Oil and Gas Drilling Competes for Water, One New Mexico County Says No', National Geographic, 3 May 2013, http://voices.nationalgeographic.com/ 2013/05/02/as-oil-and-gas-drilling-competes-for-water-one-new-mexico-county-says-no/.

99. Mark Fischetti, 'Groundwater Contamination May End the Gas-Fracking Boom', Scientific American, 20 August 2013, http://www.scientificamerican.com/article/groundwatercontamination-may-end-the-gas-fracking-boom/.

100. Anthony Ingraffea et al., 'Assessment and Risk Analysis of Casing and Cement Impairment in Oil and Gas Wells in Pennsylvania, 2000-2012', Proceedings of the National Academy of the Sciences 111, no. 30 (2014): 10955-60.

101. Sheila M. Olmstead et al., 'Shale Gas Development Impacts on Surface Water Quality in Pennsylvania', Proceedings of the National Academy of the Sciences 110, no. 13 (2013): 4962-7.

102. Paul Mobbs, 'An Abuse of Science - Concealing Fracking's Radioactive Footprint', The Ecologist, 8 July 2014, http://www.theecologist.org/News/news_analysis/2469495/an_abuse_of_ science concealing frackings radioactive footprint.html.

103. Nathaniel R. Warner et al., 'Impacts of Shale Gas Wastewater Disposal on Water Quality in Western Pennsylvania', Environmental Science \& Technology 47 no. 20 (2013): 11849-57.

104. Ibid.

105. Sean Nicholls, 'Santos Coal Seam Gas Project Contaminates Aquifer', Sydney Morning Herald, 8 March 2014, http://www.smh.com.au/environment/santos-coal-seam-gas-projectcontaminates-aquifer-20140307-34csb.html.

106. Read some examples of such in Matthew Currell, 'Coal Seam Gas Water Leaks Could be a Problem for Decades', The Conversation, 24 March 2014,http://theconversation.com/ coal-seam-gas-water-leaks-could-be-a-problem-for-decades-24718; and see farmer Brian Monk's experiences here: https://frackinginkent.wordpress.com/2014/02/01/the-ugly-truthin-queensland-australia/.

107. Avner Vengosh et al., 'A Critical Review of the Risks to Water Resources from Unconventional Shale Gas Development and Hydraulic Fracturing in the United States', Environmental Science and Technology 48, no. 15 (2014): 8334-48.

108. United Nations Sub-Commission on the Promotion and Protection of Human Rights, Realization of the Right to Drinking Water and Sanitation, Report of the Special Rapporteur, El Hadji Guissé, E/CN.4/Sub.2/2005/25 (2005).

109. United Nations Human Rights Council, Human Rights and Access to Water, A/HRC/2/104 (2006).

110. United Nations Human Rights Council, Annual Report of the United Nations High Commissioner for Human Rights on the Scope and Content of the Relevant Human Rights Obligations Related to Equitable Access to Safe Drinking Water and Sanitation under International Human Rights Instruments, A/HRC/6/3 (2007).

111. United Nations Human Rights Council, Human Rights and Access to Safe Drinking Water and Sanitation Resolution 7/22, A/HR/RES/722 (2008).

112. United Nations Human Rights Council, The Human Right to Safe Drinking Water and Sanitation, A/HRC/RES/16/2 (2011).

113. United Nations Human Rights Council, Human Rights and Access to Safe Drinking Water and Sanitation, A/HRC/RES/15/9 (2010).

114. United Nations, Convention on the Elimination of All Forms of Discrimination against Women, (1979) Article 14(2).

115. International Labour Organization, Occupational Health Services Convention C161, (1985) Article 5.

116. United Nations, The Convention on the Rights of the Child, (1989) Article 24.

117. African Commission on Human and Peoples' Rights, African Charter on the Rights and Welfare of the Child, (1990) Article 14; African Commission on Human and Peoples' Rights, Additional Protocol to the African Charter on Human and Peoples' Rights on the Rights of Women in Africa, (2003) Article 15.

118. United Nations, Convention on the Rights of Persons with Disabilities, (2006) Article 28.

119. United Nations Human Rights Council, Report of the Special Rapporteur on the Human Right to Safe Drinking Water and Sanitation, Catarina de Albuquerque: Mission to the United States of America, A/HRC/18/33/Add.4 (2011). 
120. See: US Environmental Protection Agency, Plan to Study the Potential Impacts of Hydraulic Fracturing on Drinking Water Resources, (Washington, DC: US Environmental Protection Agency, 2011), http://www2.epa.gov/hfstudy; and their study plan, http://water.epa.gov/ type/groundwater/uic/class2/hydraulicfracturing/upload/hf_study_plan_110211_final_508. pdf.

121. Ingraffea et al., 'Assessment and Risk Analysis'.

122. Vengosh et al., 'A Critical Review'.

123. Shelley and Opsal, 'Energy Crime, Harm, and Problematic State Response'.

124. Wall Street Journal, 'Online List IDs Water Wells Harmed by Drilling', Wall Street Journal, 28 August 2014, http://online.wsj.com/article/AP16a162b66b5946d0837c7395cab7a5f4.html (accessed 5 September 2014).

125. Larysa Dyrszka, Kathleen Nolan, and Sandra Steingraber, 'Statement on Preliminary Findings from the Southwest Pennsylvania Environmental Health Project Study', Concerned Health Professionals of New York, 27 August 2013, http://concernedhealthny.org/statement-onpreliminary-findings-from-the-southwest-pennsylvania-environmental-health-project-study/.

126. Dustin Bleizeffer, 'Pristine to Polluted: More Drilling Proposed near Pinedale Despite Ozone Spikes', WyoFile, 17 May 2011, http://wyofile.com/dustin/pristine-to-polluted/.

127. A dangerously toxic substance, see National Institute for Occupational Safety and Health (NIOSH), 'Emergency Preparedness and Response: Facts about Benzene', Centers for Disease Control and Prevention, 14 February 2013, http://www.bt.cdc.gov/agent/benzene/ basics/facts.asp.

128. Mariann Lloyd-Smith, 'License to Drill? Is Australia's Present Britain's Future?' (Presentation, School of Advanced Study, London, 20 May 2013), http://www.sas.ac.uk/sites/ default/files/files/events/london\%20uni\%20talk\%20Impacts\%20of\%20UG.pdf.

129. Dave Fehling, 'State Impact, Like Working in a Refinery: Fracking's New Chemical Hazards for Workers', State Impact, 24 July 2012, http://stateimpact.npr.org/texas/2012/07/24/likeworking-in-a-refinery-frackings-new-chemical-hazards-for-workers/.

130. Physicians for Social Responsibility, Hydraulic Fracturing and Your Health: Air Contamination (Washington, DC: PSR, 2014), http://www.psr.org/assets/pdfs/fracking-and-airpollution.pdf.

131. Theo Colborn et al., 'Natural Gas Operations from a Public Health Perspective', International Journal of Human and Ecological Risk Assessment 17, no. 5 (2011): 1039-56. For an analysis of chemicals found in wastewater pits, see: The Endocrine Disruption Exchange, Potential Health Effects of Residues in 6 New Mexico Oil and Gas Drilling Reserve Pits Based on Compounds Detected in at Least One Sample: Revised November 15, 2007 (Paonia, Colorado: TEDX, 2007), http://endocrinedisruption.org/assets/media/documents/summary_of_pit_ chemicals_revised_2-1-08.pdf.

132. Jessica B. Gilman et al., 'Source Signature of Volatile Organic Compounds from Oil and Natural Gas Operations in Northeastern Colorado', Environmental Science \& Technology 47, no. 3 (2013): 1297-305.

133. Wendy Koch, 'Wyoming's Smog Exceeds Los Angeles' due to Gas Drilling', USA Today, 9 March 2011, http://content.usatoday.com/communities/greenhouse/post/2011/03/wyomingssmog-exceeds-los-angeles-due-to-gas-drilling/1; Detlev Helmig, 'Highly Elevated Atmospheric Levels of Volatile Organic Compounds in the Uintah Basin, Utah', Environmental Science \& Technology 48, (2014): 4707-15.

134. Helmig, 'Highly Elevated Atmospheric Levels'. See also: American Lung Association, 'State of the Air 2014', American Lung Association, http://www.stateoftheair.org/.

135. National Institute for Occupational Safety and Health (NIOSH), 'Emergency Preparedness and Response: Facts about Benzene', Centers for Disease Control and Prevention, 14 February 2013, http://www.bt.cdc.gov/agent/benzene/basics/facts.asp.

136. Lisa M. McKenzie et al., 'Human Health Risk Assessment of Air Emissions from Development of Unconventional natural Gas Resources', Science of the Total Environment 424 (2012): 79-87.

137. Wolf Eagle Environmental, Town of DISH, Texas, Ambient Air Monitoring Analysis (Flower Mound, TX: Wolf Eagle Environmental, 2009), http://townofdish.com/objects/DISH_final_report_revised.pdf.

138. Ibid., 5.

139. Ibid., 6 . 
140. Theo Colborn et al., 'An Exploratory Study of Air Quality Near Natural Gas Operations', Human and Ecological Risk Assessment 20, no. 1 (2014): 86-105.

141. David Brown et al., 'Understanding Exposure from Natural Gas Drilling Puts Current Air Standards to the Test', Reviews Environmental Health (March 2014), http://www.degruyter. $\mathrm{com} / \mathrm{view} / \mathrm{j} / \mathrm{reveh} .2014 .29$.issue-1-2/issue-files/reveh.2014.29.issue-1-2.xml.

142. Physicians for Social Responsibility, Hydraulic Fracturing.

143. G.P. Macey, R. Breech, M. Chernaik, C. Cox, D. Larson, D. Thomas, and D.O. Carpenter, 'Air Concentrations of Volatile Compounds Near Oil and Gas Production: A Community-based Exploratory Study', Environmental Health 13, no. 82 (2014), doi:10.1186/1476-069X-13-82

144. Ibid.

145. Quoted in Alan Neuhauser, 'Toxic Chemicals, Carcinogens Skyrocket Near Fracking Sites', 30 October 2014, http://www.usnews.com/news/articles/2014/10/30/toxic-chemicals-andcarcinogens-skyrocket-near-fracking-sites-study-says.

146. Surya Deva, 'Submission to the Office of the High Commissioner for Human Rights in Relation to Equitable Access to Safe Drinking Water and Sanitation', 15 April 2007, http://www2.ohchr. org/english/issues/water/contributions/universities/CityUniversityHongKong.pdf, 2.

147. Subhash Kumar v. State of Bihar and Ors, Supreme Court of India, 1991 AIR 420.

148. Asia Pacific Forum of National Human Rights Institutions, 'Human Rights and the Environment: Final Report and Recommendations' (Final report, Asia Pacific Forum of National Human Rights Institutions, Sydney, 24-27 September, 2007), 39, http://www.ohchr.org/ Documents/Issues/ClimateChange/Submissions/Asia_Pacific_Forum_of_NHRIs_1_HR_and Environment_ACJ_Report_Recommendations.pdf. Though as this statement comes from an organisation established by the state government - and not the government itself - implementation and acceptance of such an obligation is not as assured as in the Indian context. However, as this assertion is based on numerous examples of Malaysian national and case law upholding the right of its population to a clean environment, it is relevant to include it in a discussion of the national government recognition of the right to clean air.

149. David R. Boyd, 'The Constitutional Right to a Healthy Environment', Environment: Science and Policy for Sustainable Development 54, no. 4 (2012): 3-15.

150. Organization of Africa Unity, African Charter on Human and Peoples' Rights (1981).

151. Organization of American States, Additional Protocol to the American Convention on Human Rights in the Area of Economic, Social, and Cultural Rights 'Protocol of San Salvador' (1988).

152. Lopez Ostra v. Spain, European Court of Human Rights, 16798 ECtHR 90 (1994). The court made a similar ruling in: Giacomelli v. Italy, European Court of Human Rights, 59909 ECtHR 00 (2006).

153. See: Novoselov v. Russia, European Court of Human Rights, 66460 ECtHR 01 (2005); Khudoyorov v. Russia, European Court of Human Rights, 6847 ECtHR 02 (2005); Ananyev and others v. Russia, European Court of Human Rights, 42525 ECtHR 07 (2012); and Arutyunyan v. Russia, European Court of Human Rights, 48977 ECtHR 09 (2012).

154. Öneryildiz v. Turkey, European Court of Human Rights, 48939 ECtHR 99 (2004).

155. Office of the High Commissioner for Human Right, 'Independent Expert on Human Rights and the Environment', United Nations, http://www.ohchr.org/EN/Issues/Environment/ IEEnvironment/Pages/IEenvironmentIndex.aspx.

156. Human Rights Council, Human Rights and the Environment, A/HRC/25/L.31 (2014).

157. Sub-Committee on Poverty Eradication, NGO Consultation on the Draft Guiding Principles on Extreme Poverty and Human Rights (New York: Sub-Committee on Poverty Eradication, 2011), http://www.ohchr.org/Documents/Issues/Poverty/ConsultationDGP/NGO /SubcommitteeonPovertyEradication31May2011.pdf.

158. David R. Boyd, 'The Constitutional Right to a Healthy Environment', Environment: Science and Policy for Sustainable Development 54, no. 4 (2012): 3-15.

159. See George Jucha, 'Google Earth Tour of Oil \& Gas Wells, Pads and Impoundments' (2013), https://www.youtube.com/watch?v=7jN6TSSPZwU; and Food and Water Watch, 'Fracking Infrastructure is Carving Up Pennsylvania', Food and Water Watch: Fact Sheet (December 2013), http://documents.foodandwaterwatch.org/doc/fracking_infrastructure_pennsylvania. pdf.

160. See: Michelle Bamberger and Robert E. Oswald, 'Impacts of Gas Drilling on Human and Animal Health', New Solutions 22, no. 1 (2012): 51-77; Judith Kohler, 'Report Says Drilling 
Threatens Colorado Wildlife', Aspen Times, 20 January 2010, http://www.aspentimes.com/ news/1426301-113/regional-leadstories-regionalivg-leadstoriesivg.

161. Paresh Dave, 'Ohio Finds Link between Fracking and Sudden Burst of Earthquakes', Los Angeles Times, 12 April 2014, http://www.latimes.com/nation/nationnow/la-na-nn-ohiofinds-link-fracking-earthquakes-20140411,0,570007.story\#ixzz30C04ddBj.

162. Fiona Harvey, Damian Carrington, and Terry McCallilster, 'Fracking Company Cuadrilla Halts Operations at Lancashire Drilling Site', The Guardian, 13 March 2013, http://www. theguardian.com/environment/2013/mar/13/fracking-cuadrilla-halts-operations-lancashire.

163. Shelley and Opsal, 'Energy Crime, Harm, and Problematic State Response'.

164. Heinberg, Snake Oil, 88.

165. Ibid., 89 .

166. Ibid., 88 .

167. Ibid.

168. Ibid.

169. United Nations, International Covenant on Civil and Political Rights, (1966) Article 17.

170. Council of Europe, European Convention on Human Rights, (1950) Article 8.

171. Organization of American States, American Convention on Human Rights, (1969) Article 11.

172. League of Arab States, Arab Charter on Human Rights, (2004) Article 21.

173. Kyrtatos v. Greece, European Court of Human Rights, 41666 ECtHR 98 (2003).

174. Dubetska and Others v. Ukraine, European Court of Human Rights, 30499 ECtHR 03 (2011). In this case the court did rule in favour of the complainants that a mine and factory near their homes had caused damage to their houses and therefore violated their right to respect for their private and family life and home.

175. Martinez Martinez and Maria Pino Manzano v. Spain, European Court of Human Rights, 61654 ECtHR 08 (2012).

176. Council of Europe, Protocol to the Convention for the Protection of Human Rights and Fundamental Freedoms, (1950) Article 1.

177. Organization of American States, American Convention on Human Rights, (1969) Article 21.

178. Organization of Africa Unity, African Charter on Human and Peoples' Rights, (1981) Article 14.

179. League of Arab States, Arab Charter on Human Rights, (2004) Article 31.

180. See the US and South African constitutions, as examples.

181. Flamenbaum and Others v. France, European Court of Human Rights, 23264 ECtHR 04 (2012).

182. The court also references property value in relation to environmental degradation in: Dubetska and Others v. Ukraine, European Court of Human Rights, 30499 ECtHR 03 (2011).

183. Sheila Bushkin-Bedient, Larysa Dyrszka, Yuri Gorby, and Mary Menapace, 'Compendium of Scientific, Medical, and Media Findings Demonstrating Risks and Harms of Fracking (Unconventional Gas and Oil Extraction)', Concerned Health Professionals of New York, 2nd ed. (December 2014), http://concernedhealthny.org/wp-content/uploads/2014/07/ CHPNY-Fracking-Compendium.pdf. For a report on the uncertain effects of fracking on health in Australia, see: Alicia Coram, Jeremy Moss, and Grant Blashki, 'Harms Unknown: Health Uncertainties Cast Doubt on the Role of Unconventional Gas in Australia's Energy Future', The Medical Journal of Australia 200, no. 4 (2014): 210-13.

184. Jason Morris, 'Texas Family Plagued with Ailments Gets $\$ 3 \mathrm{M}$ in 1st-of-its-kind Fracking Judgment', CNN, 26 April 2014, http://edition.cnn.com/2014/04/25/justice/texas-familywins-fracking-lawsuit/.

185. Shelley and Opsal, 'Energy Crime, Harm, and Problematic State Response'.

186. Nadia Steinzor, Wilma Subra, and Lisa Sumi, 'Investigating Links between Shale Gas Development and Health Impacts through a Community Survey Project in Pennsylvania', New Solutions 23, no. 1 (2013): 55-83.

187. For a general discussion of the chemicals released by fracking and their associated potential health effects, see: John L. Adgate, Bernard D. Goldstein, and Lisa M. McKenzie, 'Potential Public Health Hazards, Exposures and Health Effects from Unconventional Natural Gas Development', Environmental Science \& Technology 48, no. 15 (2014): 8307-20.

188. Ibid.

189. Steinzor, Subra, and Sumi, 'Investigating Links'. 
190. Sharon Wilson et al., Reckless Endangerment While Fracking the Eagle Ford (Washington, DC: Earthworks, 2013), http://www.earthworksaction.org/files/publications/FULL-Reckless Endangerment-sm.pdf.

191. Geralyn McCarron, Symptomatology of a Gas Field: An Independent Health Survey in the Tara Rural Residential Estates and Environs (2013), http://www.gabpg.org.au/wp-content/ uploads/2013/11/2013-04-symptomatology_of_a_gas_field_Geralyn_McCarron.pdf.

192. Paul Mobbs, 'Shale Gas and Public Health - The Whitewash Exposed', The Ecologist, 6 May 2014. And for a detailed critique of Public Health England's methods and conclusions see Paul Mobbs, 'A Critical Review of Public Health England's Report - "Review of the Potential Public Health Impacts of Exposures to Chemical and Radioactive Pollutants as a Result of Shale Gas Extraction - Draft for Comment"', http://www.fraw.org.uk/mei/archive/phe shale_gas_and_health_report-critical_analysis.pdf.

193. Adam Law, 'Public Health England's Draft Report on Shale Gas Extraction: Mistaking Best Practices for Actual Practices' (2014); Adam Law et al., British Medical Journal 348, 17 April 2014, http://www.bmj.com/content/348/bmj.g2728; and Mobbs, 'Shale Gas and Public Health'.

194. New York State Department of Health, 'A Public Health Review of High Volume Hydraulic Fracturing for Shale Gas Development', https://www.health.ny.gov/press/reports/docs/high volume hydraulic_fracturing.pdf.

195. See: UN Committee on Economic, Social and Cultural Rights, General Comment No. 14: The Right to the Highest Attainable Standard of Health, E/C.12/2000/4 (2000). Also important to note is that a right to health is not found in the European Convention on Human Rights, and thus the European Court often finds violations of the right to privacy in cases involving health defects from environmental degradation. See, for example: Tatar v. Romania, European Court of Human Rights, 67021 ECtHR 01 (2009).

196. Office of the High Commissioner for Human Rights, 'Special Rapporteur on the Right of Everyone to the Enjoyment of the Highest Attainable Standard of Physical and Mental Health', United Nations, http://www.ohchr.org/EN/Issues/Health/Pages/SRRightHealthIndex. aspx.

197. Anna Grear et al., A Human Rights Assessment of Hydraulic Fracturing and Other Unconventional Gas Development in the United Kingdom (London: The Bianca Jagger Human Rights Foundation, 2014), http://extremeenergy.org/category/eeiresearch/.

198. See: Öneryildiz v. Turkey, ECtHR.

199. Paul Ekins, 'The UK's New Dash for Gas is a Dangerous Gamble', The New Scientist, 6 December 2012, http://www.newscientist.com/article/dn22594-the-uks-new-dash-for-gas-isa-dangerous-gamble.html\#.VMjJI8Y12dM.

200. It is often suggested that Balcombe had little to do with fracking as it did not happen there, but in 2010 the company Cuadrilla were granted temporary planning permission by West Sussex County Council to do exactly that. 'WSCC notes that under planning permission WSCC/027/ 10/BA Cuadrilla can use hydraulic fracturing at this site.' In effect, Cuadrilla were a permit away from fracking. Furthermore, in 2011 Cuadrilla sent a letter to DECC, discovered through the court process, stating 'In order for Bolney to be successful in its Weald Basin Kimmeridge Oil Shale Project (KOSP), Bolney will need to rely, to a significant degree, on being able to undertake hydraulic fracture stimulation(s) of this unconventional reservoir.' Bolney Resources Ltd became Cuadrilla Balcombe Ltd in April 2013. (Copies of the above are held on file by the authors.)

201. For basic site information see Richard Wheatstone, 'Environmental Groups Voice Fracking Fears After "Encouraging Results" From Barton Moss Drilling', Manchester Evening News, 4 November 2014, http://www.manchestereveningnews.co.uk/news/greater-manchesternews/environmental-groups-voice-fears-over-8049913; and for the view of the company involved see http://www.igas-engage.co.uk/our-work-in-barton-moss/

202. HMSO, Human Rights Act, (1998) Article 11.

203. Council of Europe, European Convention on Human Rights, Article 11.

204. United Nations, International Covenant on Civil and Political Rights, Article 21.

205. Interview with protestor, 18 July 2014. This and the following interviews were conducted confidentially, and as such the interviewees' names have been withheld by mutual agreement.

206. Interview, 21 July 2014.

207. Interview, 18 July 2014. 
208. Ibid.

209. Ibid.

210. Interview, 21 July 2014.

211. Interview, 19 July 2014.

212. Interview, 21 July 2014.

213. Ibid.

214. Interview, 19 July 2014.

215. Interview, 21 July 2014.

216. Ibid.

217. Ibid.

218. Interview, 19 July 2014.

219. Interview, 18 July 2014.

220. Chief Superintendent Paul Morrison of Sussex police quoted in: Sandra Laville, 'Sussex Police Under Fire for “Criminalising” Fracking Protests', The Guardian, 15 May 2014, http://www. theguardian.com/environment/2014/may/15/sussex-police-criminalising-fracking-protestacquittals-balcombe.

221. BBC, 'Balcombe Anti-fracking Camp Moves to Council HQ', BBC News: Sussex, 17 November 2013, http:/www.bbc.co.uk/news/uk-england-sussex-24978363. A legal challenge, brought by the Frack Free Balcombe Residents Association against the decision of the West Sussex council to permit tests for oil after polling showed $60 \%$ of responding residents were against it, further highlights possible collusion between the council and the fracking firm Cuadrilla. Emily Gosden, 'Legal Challenge Over Plans for Fracking Firm Cuadrilla to Return to Balcombe', The Telegraph, 1 August 2014, http://www.telegraph.co.uk/earth/energy/ 11006938/Legal-challenge-over-plans-for-fracking-firm-Cuadrilla-to-return-to-Balcombe.html.

222. Salford Star, 'Salford Council Daily Barton Moss Intelligence Meetings with IGas, GMP and Peel Holdings', Salford Star, 6 August 2014, http://www.salfordstar.com/article.asp?id=2358.

223. Paul Slomp, 'Hey CSIS, Farmers Are Not Terrorists', The Star, 5 March 2013, http://www. thestar.com/opinion/commentary/2013/03/05/hey_csis_farmers_are_not_terrorists.html.

224. Robert Johnson, "Fracking Insiders Admit To Employing Military "Psychological Operations" On American Citizens', Business Insider, 9 November 2011, http:/www.businessinsider.com/ the-fracking-industry-admits-to-employing-military-psychologial-operations-on-americancitizens-2011-11.

225. Sunshine Coast Daily, 'Gas Protestors Stand Their Ground Despite Shots Being Fired', Sunshine Coast Daily, 24 May 2013, http:/www.sunshinecoastdaily.com.au/news/shotsfired-coal-seam-gas-protest-tara/1880952/.

226. Sarah Lazare, 'Protests Sweep Canada Following Paramilitary Assault on Indigenous Fracking Blockade', Common Dreams, 18 October 2013, http://www.commondreams.org/news/2013/ 10/18/protests-sweep-canada-following-paramilitary-assault-indigenous-fracking-blockade.

227. HMSO, Human Rights Act, Article 10.

228. Council of Europe, European Convention on Human Rights, Article 10.

229. United Nations, International Covenant on Civil and Political Rights, Article 19.

230. Conor Gearty, Civil Liberties (Oxford: Oxford University Press, 2007), 31.

231. Interview, 21 July 2014.

232. HMSO, Human Rights Act, Article 5.

233. Council of Europe, European Convention on Human Rights, Article 5.

234. United Nations, International Covenant on Civil and Political Rights, Article 9.

235. Interview, 18 July 2014.

236. Ibid.

237. Ibid.

238. A total of 120 people were arrested by the GMP during protests in Barton Moss (with most cleared of wrongdoing as of June 2014), while 126 were arrested by Sussex police in Balcombe (with only 29 convictions resulting). Dan Thompson, 'Most Barton Moss Protesters Cleared after Arrests', Manchester Evening News, 28 June 2014, http://www. manchestereveningnews.co.uk/news/greater-manchester-news/most-barton-moss-protesterscleared-7339995; Laville, 'Sussex Police under Fire'.

239. Interview with protestor, 21 July 2014.

240. Ibid.

241. Interview, 18 July 2014. 
242. Ibid.

243. Interview, 21 July 2014.

244. As of April 2014 - see Drill or Drop?, 'Update on Balcombe Anti-fracking Court Cases', Drill or Drop?, 8 April 2014, http://drillordrop.com/2014/04/08/update-on-balcombe-anti-frackingcourt-cases/\#more-1879.

245. Interview, 18 July 2014.

246. Ibid.

247. Ibid.

248. Ibid.

249. Ibid.

250. Interview, 21 July 2014.

251. HMSO, Human Rights Act, Article 6.

252. Council of Europe, European Convention on Human Rights, Article 6.

253. United Nations, International Covenant on Civil and Political Rights, Article 14.

254. Interviews, 21 July 2014.

255. Ibid.

256. HMSO, Human Rights Act, Article 8.

257. Council of Europe, European Convention on Human Rights, Article 8.

258. Interview, 18 July 2014.

259. Ibid.

260. Interview, 21 July 2014.

261. Interview, 19 July 2014.

262. Ibid.

263. Interview, 18 July 2014.

264. Rob Evans, 'Police Asked University for List of Attendees at Fracking Debate', The Guardian, 15 December 2014, http://www.theguardian.com/uk-news/2014/dec/15/police-university-listfracking-debate.

265. Rob Evans, 'Police Under Scrutiny After Seeking to Obtain Names of People Who Wanted to Attend University Debate', The Guardian, 5 February 2015, http://www.theguardian.com/uknews/undercover-with-paul-lewis-and-rob-evans/2015/feb/05/police-under-scrutiny-afterseeking-to-obtain-names-of-people-who-wanted-to-attend-a-debate-organised-by-academics.

266. Murray Edelman, Constructing the Political Spectacle (Chicago, IL: University of Chicago Press, 1998).

267. See James Perkins, 'Biggest Weekly Oil Rig Decline since 1987', The Shale Energy Insider, 2 February 2015, http://www.shaleenergyinsider.com/2015/02/02/biggest-weekly-oil-rigdecline-since-1987/; and for a UK perspective Anthony Hilton, 'Fracking Just Doesn't Pay So Why Bother?' The Evening Standard, 3 February 2015, http://www.standard.co.uk/ business/markets/anthony-hilton-fracking-just-doesnt-pay-so-why-bother-10020898.html.

268. Paul Mobbs, 'With Sub-\$60 Oil, Fracking and Tar Sands Losses Threaten the Whole Financial System'. The Ecologist, 17 December 2014, http://www.theecologist.org/News/news analysis/2679765/with_sub60_oil_fracking_and_tar_sands_losses_threaten_the_whole_ financial_system.html.

269. Noam Chomsky, Profit over People: Neoliberalism and the Global Order (New York: Seven Stories Press, 1999), 96.

270. de Rijke, 'Hydraulically Fractured', 15.

271. Damian Carrington, 'Owen Paterson Held Urgent Meeting for Fracking Boss, Documents Show', The Guardian, 21 March 2014, http://www.theguardian.com/environment/2014/ mar/21/owen-paterson-urgent-meeting-fracking-cuadrilla-lord-browne; and 'Emails Reveal UK Helped Shale Gas Industry Manage Fracking Opposition', The Guardian, 17 January 2014, http://www.theguardian.com/environment/2014/jan/17/emails-uk-shale-gas-frackingopposition; and 'George Osborne Urges Ministers to Fast-track Fracking Measures in Leaked Letter', The Guardian, 26 January 2015, http://www.theguardian.com/environment/ 2015/jan/26/george-osborne-ministers-fast-track-fracking.

272. Paul Mobbs, "Economically \& Politically Fracked: "Behind Every Picture Lies a Story" - Statistical Reality Versus PR-hype Within the Political Project of Unconventional Gas in Britain', Extreme Energy Initiative, Working Papers Series (2013), http://extremeenergy.org/2013/07/ 25/economically-and-politically-fracked-behind-every-picture-lies-a-story-statistical-realityversus-pr-hype-within-the-political-project-of-unconventional-gas-in-britain/. 
273. David Cameron, 'We Cannot Afford to Miss Out on Shale Gas', The Telegraph, 11 August 2013, http://www.telegraph.co.uk/news/politics/10236664/We-cannot-afford-to-miss-out-onshale-gas.html.

274. Paul Mobbs, 'Fracking Policy and the Pollution of British Democracy', The Ecologist, 20 January 2015, http://www.theecologist.org/News/news_analysis/2721027/frackingnbsppolicy_and_the pollution_of_british_democracy.html.

275. International Energy Agency, Word Energy Outlook 2012 (2012), Executive Summary, 3, $\mathrm{http}: / / w w w . i e a . o r g / p u b l i c a t i o n s /$ freepublications/publication/English.pdf.

276. Christophe McGlade and Paul Ekins 'The Geographical Distribution of Fossil Fuels Unused When Limiting Global Warming to $2{ }^{\circ} \mathrm{C}$ ', Nature 517 (2015): 187-90.

277. James Hansen, Storms of my Grandchildren: The Truth about the Coming Climate Catastrophe and Our Last Chance to Save Humanity (London: Bloomsbury, 2009), 289.

278. Yale Environment 360, 'Forum: Just How Safe Is “Fracking” of Natural Gas?', Yale Environment 360, http://e360.yale.edu/feature/forum_just_how_safe_is_fracking_of_natural_gas/ 2417/. See also http://kevinanderson.info/blog/uk-international-commitments-on-climatechange-are-incompatible-with-the-development-of-a-national-shale-gas-industry/.

279. Shelia Watt-Cloutier, Petition to the Inter American Commission on Human Rights Seeking Relief from Violations Resulting from Global Warming Caused by Acts and Omissions of the United States (Nunavut, Canada: Inuit Circumpolar Conference, 2005), http://earthjustice. org/sites/default/files/library/legal_docs/petition-to-the-inter-american-commission-on-humanrights-on-behalf-of-the-inuit-circumpolar-conference.pdf.

280. Ariel E. Dulitaky to Paul Crowley, Inadmissibility of Watt-Cloutier Petition, Washington, DC, 16 November 2006, http://graphics8.nytimes.com/packages/pdf/science/16commissionletter. pdf.

281. Humphreys, Climate Change and Human Rights.

282. United Nations Human Rights Council, Resolution 7/23 (2008).

283. Office of the High Commissioner for Human Rights, Report of the Office of the United Nations High Commissioner for Human Rights on the Relationship between Climate Change and Human Rights, A/HRC/10/61 (2009).

284. United Nations Human Rights Council, Resolution 10/4 (2009).

285. Office of the High Commissioner for Human Rights, Human Rights Council Panel Discussion on the Relationship between Climate Change and Human Rights (Geneva: Office of the High Commissioner for Human Rights, 2009).

286. Office of the High Commissioner for Human Rights, 'Human Rights and Climate Change: Overview', United Nations, http://www.ohchr.org/EN/Issues/HRAndClimateChange/Pages/ HRClimateChangeIndex.aspx.

287. The recent vote in Denton, Texas to ban fracking highlights the sentiments of residents who are no stranger to the fossil fuel industry. Suzanne Goldenberg, 'Texas Oil Town Makes History as Residents Say No to Fracking', The Guardian, 5 November 2014, http://www.theguardian. com/environment/2014/nov/05/birthplace-frackingboom-votes-ban-denton-texas.

288. Mobbs, 'Shale Gas and Public Health'.

289. Zachary Boren, 'Energy Files: Social impacts of fracking REDACTED', Greenpeace Energy Desk, 11 August 2014, http://energydesk.greenpeace.org/2014/08/11/energy-files-socialimpacts-fracking-redacted/. 